Article

\title{
A New Class of $\beta$-Pyrrolidino-1,2,3-Triazole Derivatives as $\beta$-Adrenergic Receptor Inhibitors: Synthesis, Pharmacological, and Docking Studies
}

\author{
Kaliyappan Easwaramoorthi ${ }^{1,2}$, Jeya A. Rajendran ${ }^{1, *}$, Kella Chennakesava Rao ${ }^{2,3}$, \\ Chandrasekar Balachandran ${ }^{4}$, Yuvaraj Arun ${ }^{3}{ }^{-}$, Sakkarapalayam M. Mahalingam ${ }^{5}$, \\ Natarajan Arumugam ${ }^{6}{ }^{\circ}$, Abdulrahman I. Almansour ${ }^{6}$, Raju Suresh Kumar ${ }^{6}$, \\ Dhaifallah M. Al-thamili ${ }^{6}$ (D) and Shin Aoki ${ }^{4,7}$ (1) \\ 1 Department of Chemistry, Loyola College, Chennai 600034, TN, India; kemysv.2018@gmail.com \\ 2 R\&D Centre, Malladi Drugs \& Pharmaceuticals Ltd., Chennai 600124, TN, India; kcrao2009@gmail.com \\ 3 Organic \& Bioorganic Chemistry Laboratory, CSIR-Central Leather Research Institute, Adyar, \\ Chennai 600020, TN, India; arun.y.chem@gmail.com \\ 4 Faculty of Pharmaceutical Sciences, Tokyo University of Science, 2641 Yamazaki, Noda 278-8510, Japan; \\ balaeri09@gmail.com (C.B.); shinaoki@rs.noda.tus.ac.jp (S.A.) \\ 5 Department of Chemistry, SRM institute of Science and Technology, Kattankulathur, Kancheepuram 603203, \\ India; mahalins@srmist.edu.in \\ 6 Department of Chemistry, College of Science, King Saud University, P.O. Box 2455, Riyadh 11451, \\ Saudi Arabia; anatarajan@ksu.edu.sa (N.A.); almansor@ksu.edu.sa (A.I.A.); sraju@ksu.edu.sa (R.S.K.); \\ daife54321@hotmail.com (D.M.A.) \\ 7 Research Institute of Science and Technology, Tokyo University of Science, 2641 Yamazaki, \\ Noda 278-8510, Japan \\ * Correspondence: jeyarajendran@yahoo.com; Tel.: +91-944-411-6528
}

Received: 4 August 2019; Accepted: 24 September 2019; Published: 26 September 2019

\begin{abstract}
New 1,4-disubstituted $\beta$-pyrrolidino-1,2,3-triazoles were synthesized using a reusable copper-iodide-doped neutral alumina catalyst. Synthesis of diversely substituted triazoles and recyclability of CuI catalyst explains the broad scope of this protocol. The synthesized compounds were screened for their antimicrobial and anticancer properties. Most of the compounds showed significant antimicrobial activities against all the tested microorganisms compared to standard drugs. Furthermore, compounds $\mathbf{5 a}, \mathbf{5 e}, \mathbf{5 g}, \mathbf{5 h}, \mathbf{5 i}$, and $\mathbf{5 j}$ showed moderate to potent activities against A549 and HepG-2 cells. In addition, compounds $\mathbf{5 g}$ and $\mathbf{5 h}$ displayed potential cytotoxicity activity against A549 cells with $\mathrm{IC}_{50}$ values of $72 \pm 3.21$ and $58 \pm 2.31 \mu \mathrm{M}$, respectively. The molecular docking study revealed that some of the synthesized compounds exhibited comparable binding as co-crystalized ligands with the DNA topoisomerase IV and anaplastic lymphoma kinase receptors.
\end{abstract}

Keywords: $\beta$-pyrrolidino-1,2,3-triazole; $\beta$-adrenoceptors; antimicrobial activity; anticancer activity; docking studies

\section{Introduction}

Cancer is a multi-factorial genetic disease whose development involves a multitude of genes [1]. Microarray analyses have identified thousands of genes that are over- or under-expressed in specific tumor samples. However, the use of more specific techniques, such as real-time quantitative polymerase chain reactions, is necessary to further investigate the involvement of each of these genes [2]. $\beta$-Adrenergic receptors transduce signals from catecholamines to the $G$ protein, which through a cascade of chemical reactions, generates highly specific parallel signals with neuroendocrine 
functions in cells. Previous studies have established a relationship between the $\beta_{2}$-adrenergic receptor and various aspects related to cancer. This receptor appears to be mainly associated with cell proliferation, apoptotic phenomena [3,4], chemotaxis, the development of metastasis $[5,6]$, tumor growth, and angiogenesis [7].

In their role as $\beta$-adrenergic receptor agonists, catecholamines and, in particular, epinephrine and norepinephrine are directly involved in increasing the metastatic capacity and apoptosis resistance of carcinogenic cells. $\beta$-Adrenergic receptors, in particular $\beta_{1}$ - and $\beta_{2}$-receptors, have also been found to be expressed in colon cancer cell lines [8] and oral squamous cell carcinoma (OSCC) [9]. In OSCC, it appears that the over-expression of $\beta_{2}$-adrenergic receptors in TCa8113 and ACC cells and the use of the $\beta$-adrenergic receptor agonist norepinephrine cause a potent mitogenic effect that increases tumor size, while the antagonist propranolol, in contrast, completely inhibits these receptors (Figure 1).

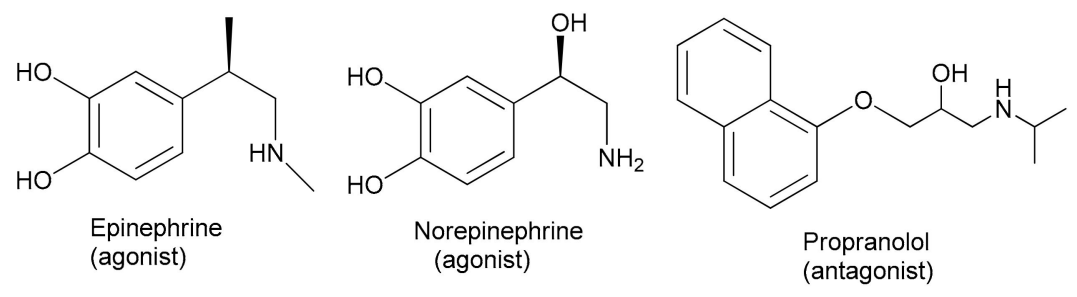

Figure 1. Structures of $\beta$-adrenergic receptor agonists and antagonist.

A recent in vivo study using colon cancer xenografts showed an association between nicotine and increased tumor size and vascularization that was attributable to an increase in the synthesis of COX-2 (Cyclooxygenase-2) prostaglandin E2, and VEGF (Vascular Endothelial Growth Factor) mediated by $\beta$-adrenergic receptors, particularly $\beta 2$ receptors [9]. Therefore, the development of novel $\beta$-adrenergic receptor inhibitors possessing improved pharmaceutical profiles and reduced adverse effects is still urgently needed. Various potent pharmacological activities [10-12] of pyrrolidinyl triazoles including anticancer potential and acting as MPTP (Mitochondrial Permeability Transition Pore) blockers prompted us to explore 1,4-disubstituted $\beta$-pyrrolidino-1,2,3-triazoles as $\beta$-adrenergic receptor inhibitors. The synthesis was accomplished as described in Scheme 1 from pyrrolidinylnorephedrine using copper-catalyzed 1,3-dipolar cycloaddition with azide and terminal alkyne as an application of click chemistry $[13,14]$.

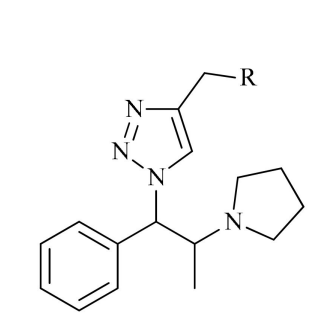

Novel $\beta$-adrenergic receptors

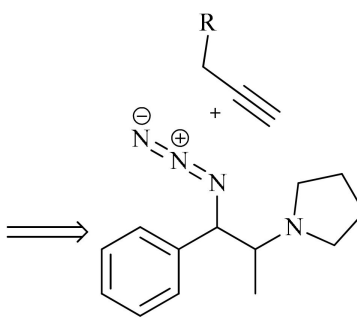

Azide and terminyl alkyne

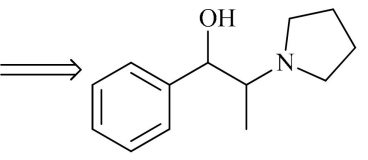

Pyrrolidinylnorephedrine

Scheme 1. Design strategy for new $\beta$-adrenergic receptor inhibitors.

\section{Results and Discussions}

\subsection{Chemistry}

Our synthetic study began with a readily available starting precursor $(1 R, 2 S)$-pyrrolidinylnorephedrine $\mathbf{1}$ (PNE) being subjected to sequence of transformations as outlined in Scheme 1. Thus, PNE 1 received treatment with thionyl chloride under refluxing condition in chloroform and was converted into its chloro derivative 2 , which upon treatment with sodium azide in $\mathrm{N}, \mathrm{N}$-dimethylformamide (DMF) at ambient temperature for $12 \mathrm{~h}$, produced the 
azide $\mathbf{3}$ in quantitative yield (Scheme 1). Finally, the terminal alkynes $\mathbf{4 a - 1}$ (except $\mathbf{4 a - b}$ and $\mathbf{4 f}$ [15]) were allowed to react with azide 3 employing copper-catalyzed 1,3-dipolar cycloaddition (also known as $\mathrm{CuAAC}$ - copper catalyzed azide-alkyne-cycloaddition), which produced the target novel 1,4-disubstituted $\beta$-pyrrolidino-1,2,3-triazoles 5a-1 as an application of click chemistry (Scheme 2).

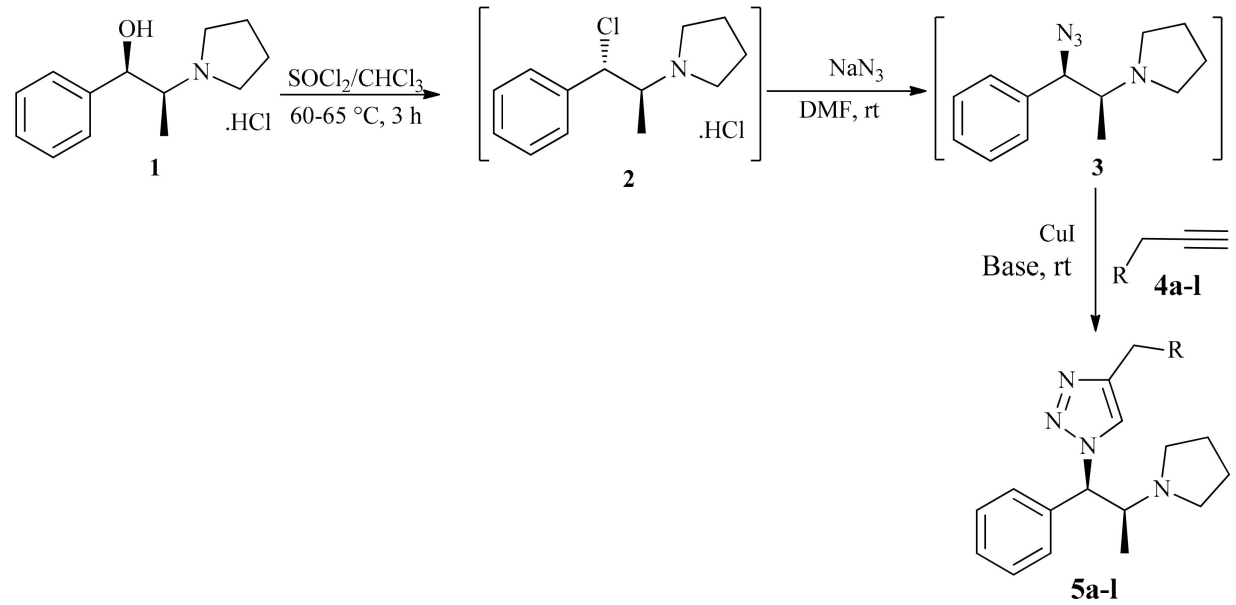

Scheme 2. Synthesis of novel $\beta$-pyrrolidino-1,2,3-triazoles by CuAAC.

An optimization study was performed using propargyl alcohol $\mathbf{4 a}$ as a terminal alkyne. The yield of $\mathbf{5 a}$ was considered as a target in all experiments during this optimization study. Various reaction conditions, such as the concentration of copper iodide, supported on alumina, various solvents, and temperature, have been studied to establish the best condition for the formation of novel 1,4-disubstituted $\beta$-amino-1,2,3-triazole 5a in good yield (Table 1).

Table 1. Optimization of reaction conditions.

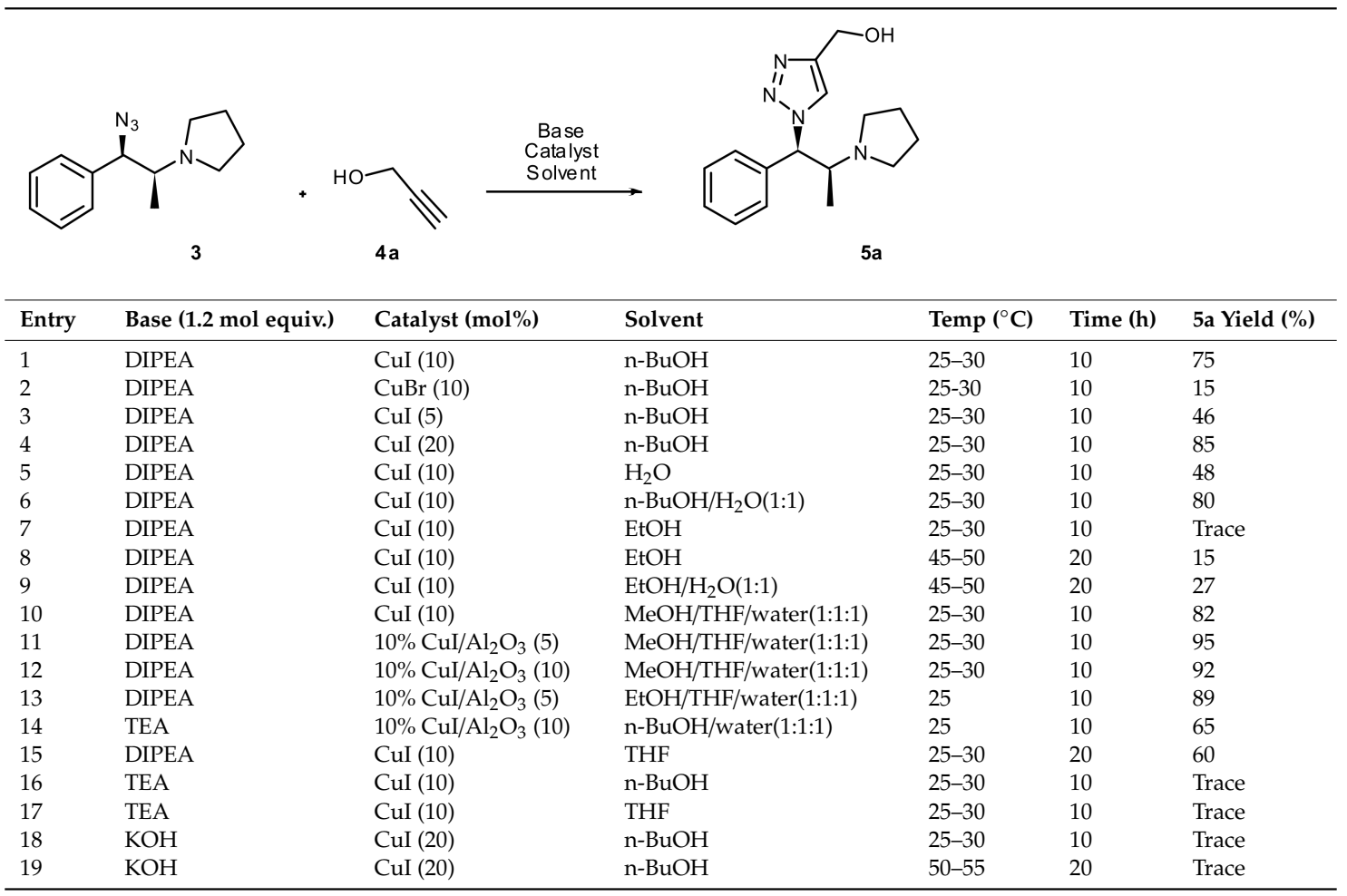

* Isolated yields after recrystallization in acetone. 
Bases such as diisopropylethylamine (DIPEA), triethylamine (TEA), and potassium hydroxide were used and better yields were noticed with DIPEA. Solvents such as various alcohols and tetrahydrofuran (THF) were used and good results were found with the usage of a mixture of solvent that consisted of alcohol (methanol or ethanol), THF, and water in an equimolar ratio. Among copper bromide and copper iodide as catalysts, the reaction proceeded well with copper iodide. From Table 1 and entry 11 , it was understood that usage of $10 \%$ copper iodide/alumina $\left(\mathrm{CuI} / \mathrm{Al}_{2} \mathrm{O}_{3}\right)$ in $5 \mathrm{~mol} \%$ produced compound 5a with a 95\% yield. Another advantage of the used catalyst is that it can be reusable without a loss of its efficiency. After each reaction, the catalyst was washed with methanol, dried at $100{ }^{\circ} \mathrm{C}$, and reused. In our study, the catalyst was recycled 10 times and produced satisfactory yields in-between $90 \%$ and $95 \%$ (Figure 2). However, additional time was required for the completion of the reaction. The time required for the completion of the reaction for the first and tenth cycles was $8 \mathrm{~h}$ and $20 \mathrm{~h}$, respectively.

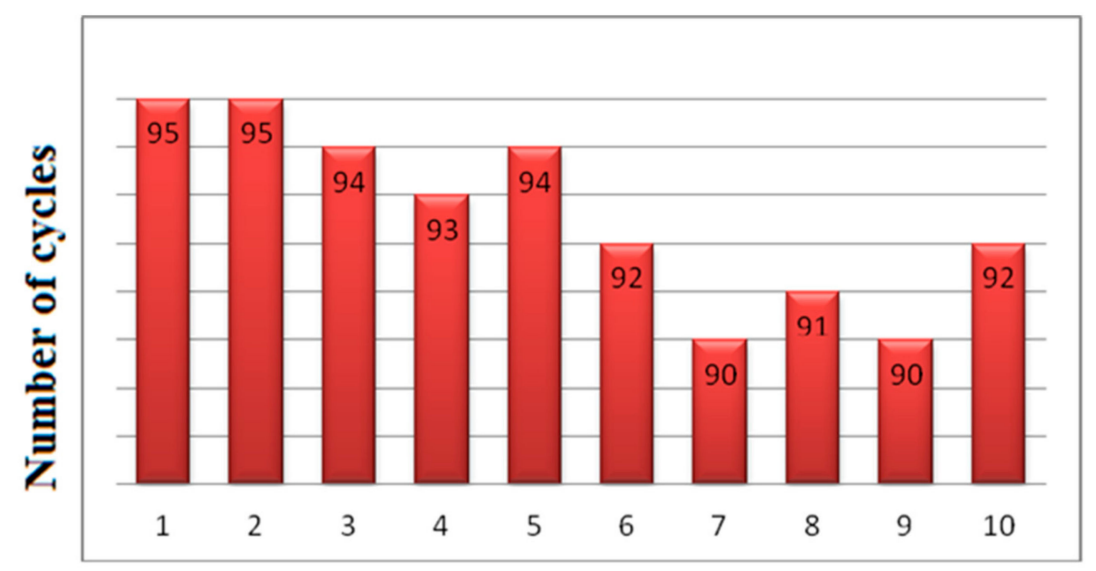

\section{Yield of reaction}

Figure 2. Re-usage of catalyst: Number of cycles vs. yield of reaction, $\mathbf{5 a}$.

Usage of $\mathrm{CuI} / \mathrm{Al}_{2} \mathrm{O}_{3}$ in click chemistry has already been reported [16] under microwave treatment, which is not feasible at the industrial scale [17] and it is an expensive technique. From Table 1, it was concluded that the usage of $5 \mathrm{~mol} \%$ of $\mathrm{CuI} / \mathrm{Al}_{2} \mathrm{O}_{3}$ catalyst, DIPEA as a base, and a mixture of methanol/THF/water as a solvent system at $25^{\circ} \mathrm{C}$ to $30^{\circ} \mathrm{C}$ produced the required compound 5 a with a very good yield (95\%). The same reaction condition was used for subsequent reactions ( $5 \mathbf{b}-\mathbf{1}$, Table 2 ).

For this activity, we used hydrochloride salt of $(1 R, 2 S)$-pyrrolidinylnorephedrine $\mathbf{1}$ [18], which was synthesized from $(1 R, 2 S)$-phenylpropnaolamine. Since the key starting material $\mathbf{1}$ is chiral, the final triazoles 5a-1 should also be chiral. During chlorination of $\mathbf{1}$ (Scheme 2), the inversion took place at the benzylic carbon followed by another inversion through an azidation reaction, which resulted in an overall retention of the configuration at the benzylic carbon. Analysis of the isolated compounds using chiral HPLC (High Performance Liquid Chromatography) shows that all compounds were chirally pure. The specific optical rotation was not measured since the solution of the compounds ( $1 \%$ concentration in methanol or chloroform) was quite dark due to the dark colors of the products (brown solids) and a zero reading was observed with the polarimeter. 
Table 2. Synthesis of compounds $\mathbf{5 a}-\mathbf{1}$ from optimized conditions.

\begin{tabular}{|c|c|c|c|c|c|c|c|}
\hline Entry & Terminal Alkyne & $\beta$-pyrrolidino-1,2,3-triazole & Yield $\%$ & Entry & Terminal Alkyne & $\beta$-pyrrolidino-1,2,3-triazole & Yield \% \\
\hline 1 & $4 \mathbf{a}$ & $5 a$ & 95 & 7 & $4 g$ & $5 g$ & 80 \\
\hline 2 & $4 b$ & $5 b$ & . & . & $\mathrm{MeO}^{-}$ & $5 \mathrm{~h}$ & . \\
\hline 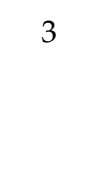 & $4 c$ & $5 c$ & 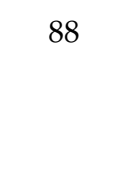 & . & $4 i$ & $5 i$ & 90 \\
\hline 4 & $4 d$ & $5 d$ & 96 & 10 & $4 j$ & $5 \mathbf{j}$ & 84 \\
\hline
\end{tabular}


Table 2. Cont

Entry Terminal Alkyne $\quad \beta$-pyrrolidino-1,2,3-triazole


Chiral HPLC analysis: Compound 5a was prepared from two separate experiments as per the established method (Scheme 2). In the first experiment $(1 R, 2 S)$-pyrrolidinylnorephedrine 1 was used and in the second experiment racemic-pyrrolidinylnorephedrine was used. The obtained compounds from both the experiments were analyzed using normal HPLC and chiral HPLC. In normal HPLC, only one peak was found for the compound, which was obtained from both the experiments at the same retention time (RT). However, in chiral HPLC, the compound obtained from the first experiment showed one major peak with an area $\%$ above $99 \%$. The compound obtained from the second experiment showed two peaks using chiral HPLC with an equal intensity and the retention time of one peak was matched with the compound of the first experiment. This study indicated that the compound obtained from the first experiment was a chiral one with enantiomeric excess (ee) above $99 \%$ and the compound obtained from the second experiment was a racemic mixture (vide infra, Supplementary Materials).

The structures of the synthesized novel 1,4-disubstituted- $\beta$-pyrrolidino-1,2,3-triazoles 5a-1 (Table 2) were well established using FT-IR, ${ }^{1} \mathrm{H}-\mathrm{NMR},{ }^{13} \mathrm{C}-\mathrm{NMR}$, and mass spectroscopy. As a representative case, the structural elucidation of compound $5 \mathrm{~h}$ is described here. In the IR spectrum $(\mathrm{KBr})$ of $5 \mathrm{~h}$, the medium bands at 3142, 3086, 3063, 2965, and $2905 \mathrm{~cm}^{-1}$ indicated stretching frequencies of aliphatic and aromatic $\mathrm{C}-\mathrm{H}$. The sharp band at $1701 \mathrm{~cm}^{-1}$ indicated the presence of ester carbonyl and the bands at 1599 and $1514 \mathrm{~cm}^{-1}$ confirmed benzenoid stretching frequencies. The bands at $1342 \mathrm{~cm}^{-1}$ and $1291 \mathrm{~cm}^{-1}$ confirmed the presence of $\mathrm{C}-\mathrm{N}$ (aromatic) and $\mathrm{C}-\mathrm{O}$ (aromatic ester) groups, respectively. Two characteristic bands at 1020 and $949 \mathrm{~cm}^{-1}$ represented $\mathrm{C}-\mathrm{H}$ bending frequencies of the 1,2,3-triazole ring [19]. The presence of bands at 843 and $785 \mathrm{~cm}^{-1}$ indicated $\mathrm{C}-\mathrm{H}$ bending frequencies of the trisubstituted phenyl ring and a band at $768 \mathrm{~cm}^{-1}$ represented a mono-substituted phenyl ring.

In the ${ }^{1} \mathrm{H}-\mathrm{NMR}$ spectrum of $5 \mathbf{h}$, the doublet signal at $\delta_{\mathrm{H}} 1.02 \mathrm{ppm}(J=1.2 \mathrm{~Hz})$ indicated the presence of three protons of the aliphatic $\mathrm{CH}_{3}$ group. A broad multiplet signal at $\delta_{\mathrm{H}} 1.66 \mathrm{ppm}$ showed four protons of two $\mathrm{CH}_{2}$ 's of a pyrrolidinyl ring at the $\mathrm{C}_{3}$ and $\mathrm{C}_{4}$ carbons. Another broad multiplet signal at $\delta_{\mathrm{H}} 2.59-2.61 \mathrm{ppm}$ indicated four protons of two $\mathrm{CH}_{2}$ groups of a pyrrolidinyl ring at the $\mathrm{C}_{2}$ and $C_{5}$ carbons. Two sharp singlet signals at $\delta_{\mathrm{H}} 3.92 \mathrm{ppm}$ and $3.94 \mathrm{ppm}$ confirmed six protons of two $\mathrm{OCH}_{3}$ groups attached to a phenyl ring at the $p$ - and $m$-positions. A singlet signal present at $\delta_{\mathrm{H}}$ $5.45 \mathrm{ppm}$ showed two protons of the $\mathrm{OCH}_{2}$ group. The signals at $\delta_{\mathrm{H}} 6.87 \mathrm{ppm}$ and $6.89 \mathrm{ppm}$ were ascribed to two methine protons. A multiplet signal appearing in between $\delta_{\mathrm{H}} 7.28 \mathrm{ppm}$ and $7.87 \mathrm{ppm}$ confirmed nine aromatic protons.

In the ${ }^{13} \mathrm{C}-\mathrm{NMR}$ spectrum of $5 \mathrm{~h}$, the signal at $\delta_{\mathrm{C}} 11.39 \mathrm{ppm}$ indicated aliphatic $\mathrm{CH}_{3}$ carbon. Two signals appearing at $\delta_{C} 58.11$ and 58.39 ppm confirmed two carbons of two methoxy groups attached to a phenyl ring and another signal at $69.46 \mathrm{ppm}$ confirmed carbon of a $\mathrm{OCH}_{2}$ group attached to a triazole ring. Twelve signals appearing in between 110.24 and $153.13 \mathrm{ppm}$ showed twelve aromatic carbons and a signal at $166.24 \mathrm{ppm}$ explained the presence of the carbonyl carbon of an ester group of 5 h.

The distinguishing peak observed at $\mathrm{m} / \mathrm{z} 451$ in the ESI (Electrospray Ionization) mass spectrum confirmed the protonated molecular ion $[\mathrm{M}+\mathrm{H}]^{+}$of compound $5 \mathbf{h}$. A single crystal XRD study was not carried out as suitable crystals were not obtained from the crystallization of any of the synthesized compound. Various methods and solvents were tried for crystallization to get a suitable crystal for a single-crystal XRD study. However, all efforts resulted in an amorphous powder, which was not suitable for single-crystal XRD analysis.

\subsection{Antimicrobial Activity}

In the present study, the antimicrobial activities of synthesized compounds were screened against ten bacteria and two fungi using an in vitro well method $[19,20]$. The results are summarized below (Tables 3 and 4). In particular, compounds $\mathbf{5 a}, \mathbf{5} \mathbf{g}, \mathbf{5 h}, \mathbf{5 j}$, and $\mathbf{5} \mathbf{k}$ showed promising activity against tested bacteria at a $1 \mathrm{mg} / \mathrm{mL}$ concentration. Compound $5 \mathrm{~g}$ exhibited significantly potent antimicrobial activity against the tested bacteria. The MIC (Minimum Inhibitory Concentration) value of compound 
$5 \mathrm{~g}$ was found to be $31.25 \mu \mathrm{g} / \mathrm{mL}$ against K. pneumonia, S. flexneri, P. vulgaris, S. aureus-MRSA and S. epidermidis.

Table 3. Antimicrobial activity of the synthesized compound using a well method (zone of inhibition in $\mathrm{mm})(1 \mathrm{mg} /$ well $)$.

\begin{tabular}{lccccccccccccc}
\hline Organism & $\mathbf{5 a}$ & $\mathbf{5 b}$ & $\mathbf{5 c}$ & $\mathbf{5 d}$ & $\mathbf{5 e}$ & $\mathbf{5 f}$ & $\mathbf{5 g}$ & $\mathbf{5 h}$ & $\mathbf{5 i}$ & $\mathbf{5 j}$ & $\mathbf{5 k}$ & $\mathbf{5 1}$ & $\mathbf{C}$ \\
\hline Bacteria & & & & & & & & & & & & \\
Enterobacter aerogenes & 14 & 12 & 14 & 10 & 10 & - & 22 & 17 & 14 & - & 22 & - & 22 \\
Staphylococcus aureus & 12 & 10 & 16 & 13 & 12 & - & 16 & 15 & 16 & 15 & 18 & - & 14 \\
Staphylococcus epidermidis & 14 & 10 & 15 & 13 & 10 & 17 & 28 & 16 & 11 & 14 & - & - & 26 \\
Staphylococcus aureus-MRSA & 13 & 12 & 18 & 16 & 10 & 15 & 24 & 20 & 14 & 14 & 17 & - & 30 \\
Salmonella paratyphi-B & 14 & 11 & 14 & 14 & 10 & 14 & 20 & 19 & 12 & 18 & 18 & - & 18 \\
Salmonella typhimurium & 14 & 11 & 12 & 12 & 12 & - & 22 & 22 & - & 20 & 15 & - & 24 \\
Proteus vulgaris & 17 & 12 & 10 & - & 13 & - & 26 & 23 & - & 20 & 16 & - & 30 \\
Micrococcus luteus & 28 & 13 & 16 & 19 & 15 & 13 & 17 & 14 & 16 & 16 & - & - & 26 \\
Klebsiella pneumoniae & 20 & 10 & 12 & - & 10 & 18 & 24 & 20 & 12 & 22 & 14 & - & 20 \\
Shigella flexneri & 22 & - & 13 & 13 & 15 & 19 & 25 & 18 & 14 & 22 & 17 & - & 30 \\
Fungi & & & & & & & & & & & & & C \\
Candida albicans & 14 & - & - & 13 & 15 & - & 13 & - & 12 & 13 & - & - & 28 \\
Malassezia pachydermatis & 12 & - & - & 10 & 14 & 12 & - & - & 10 & 11 & - & 12 & 26 \\
\hline
\end{tabular}

C-Streptomycin—standard antibacterial agent; C-Ketoconazole—-standard antifungal agent.

Table 4. Minimum inhibitory concentration of the synthesized compounds ( $\mu \mathrm{g} / \mathrm{mL}$ ).

\begin{tabular}{ccccccccccc}
\hline Organism & $\mathbf{5 a}$ & $\mathbf{5 c}$ & $\mathbf{5 d}$ & $\mathbf{5 f}$ & $\mathbf{5 g}$ & $\mathbf{5 h}$ & $\mathbf{5 i}$ & $\mathbf{5 j}$ & $\mathbf{5 k}$ & $\mathbf{C}$ \\
\hline Bacteria & & & & & & & & & & \\
Enterobacter aerogenes & 250 & 250 & 500 & - & 62.5 & 125 & 250 & - & 62.5 & 25 \\
Staphylococcus aureus & 500 & 125 & 250 & - & 125 & 250 & 125 & 250 & 125 & 6.25 \\
Staphylococcus epidermidis & 250 & 250 & 250 & 125 & 31.25 & 125 & 500 & 250 & - & 25 \\
Staphylococcus aureus-MRSA & 250 & 125 & 125 & 250 & 31.25 & 62.5 & 250 & 250 & 125 & 6.25 \\
Salmonella paratyphi-B & 250 & 250 & 250 & 250 & 62.5 & 62.5 & 500 & 125 & 125 & 30 \\
Salmonella typhimurium & 250 & 500 & 500 & - & 62.5 & 62.5 & - & 62.5 & 250 & 6.25 \\
Proteus vulgaris & 125 & 500 & - & - & 31.25 & 62.5 & - & 62.5 & 125 & 6.25 \\
Micrococcus luteus & 31.25 & 125 & 62.5 & 250 & 125 & 250 & 125 & 125 & - & 6.25 \\
Klebsiella pneumoniae & 62.5 & 500 & - & 125 & 31.25 & 62.5 & 500 & 62.5 & 250 & 25 \\
Shigella flexneri & 62.5 & 250 & 250 & 62.5 & 31.25 & 125 & 250 & 62.5 & 125 & 6.25 \\
\hline
\end{tabular}

\subsection{Anticancer Results}

Anticancer activity studies were performed for the synthesized compounds $\mathbf{5 a}, \mathbf{5 e}$, and $\mathbf{5} \mathbf{g}-\mathbf{j}$ (which showed higher antimicrobial activity than the others) against A549 and HepG-2 cells [15,21]. All the tested compounds showed good cytotoxic activity against A549 cells. However, 5a, 5e, 5i, and 5j showed good in vitro cytotoxic activity against both A549 and HepG-2 cells (Figure 3). However, 5a, 5e, and $\mathbf{5 i}$ showed moderate activity against HepG-2 cells (Table 5). The cytotoxicity properties of synthesized compounds against A549 cells were observed at concentrations of $275 \mu \mathrm{M}$ to $58 \mu \mathrm{M}$. The cytotoxic results showed that among all the tested compounds, $\mathbf{5 a}, \mathbf{5 e}, \mathbf{5 g}, \mathbf{5 h}, \mathbf{5 i}$, and $5 \mathbf{j}$ showed promising anticancer activity against A549 cells. Compounds $\mathbf{5 g}$ and $\mathbf{5 h}$ showed potent cytotoxic activity against $\mathrm{A} 549$ cells with $\mathrm{IC}_{50}$ values of 72 and $58 \mu \mathrm{M}$, respectively (Table 5). A toxicity study of all synthesized compounds including $\mathbf{5 a}, \mathbf{5 e}$, and $\mathbf{5} \mathbf{g}-\mathbf{j}$ against human normal IMR90 cells showed no toxicity up to $250 \mu \mathrm{M}$ (vide infra, supporting information). 
(A) $\mathrm{A549}$

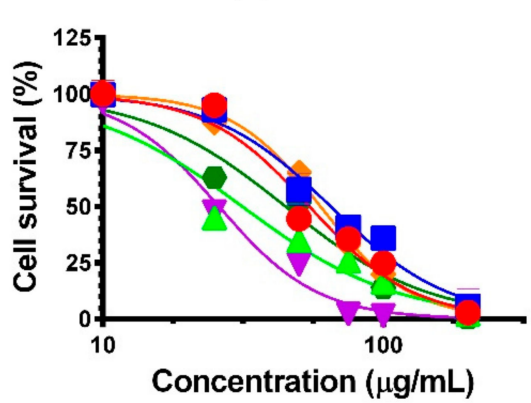

(B) HepG-2

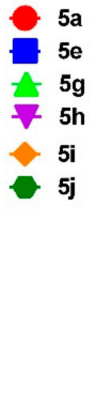

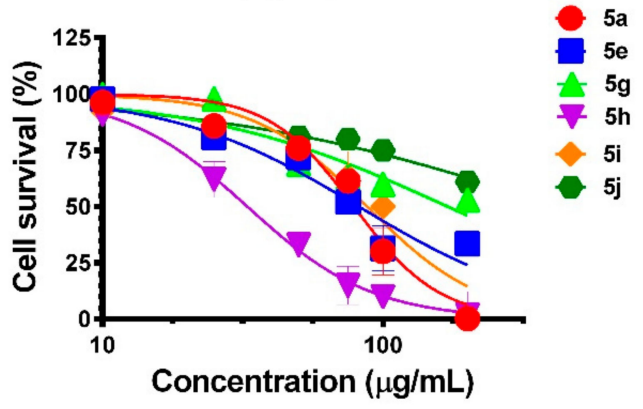

Figure 3. Effect of synthesized compounds against (A) A549 and (B) HepG-2 cells. Data were calculated using three independent experiments with mean \pm SD.

Table 5. $\mathrm{IC}_{50}(\mu \mathrm{M})$ values of synthesized compounds against IMR90, A549, and HepG-2 cells.

\begin{tabular}{cccc}
\hline Compound & A549 & HepG-2 & IMR90 \\
\hline $5 \mathrm{a}$ & $190 \pm 1.35$ & $275 \pm 1.52$ & $>250$ \\
\hline $5 \mathrm{e}$ & $130 \pm 0.65$ & $164 \pm 2.01$ & $>250$ \\
\hline $5 \mathrm{~g}$ & $\mathbf{7 2} \pm 3.21$ & $>300$ & $>250$ \\
\hline $5 \mathrm{~h}$ & $\mathbf{5 8} \pm 2.31$ & $\mathbf{7 3} \pm 3.88$ & $>250$ \\
\hline $5 \mathrm{i}$ & $134 \pm 1.05$ & $197 \pm 2.34$ & $>250$ \\
\hline $5 \mathrm{j}$ & $111 \pm 1.82$ & $>300$ & $>250$ \\
\hline Cisplatin $(\mu \mathrm{M})$ & $16.4 \pm 3.19$ & $22.1 \pm 3.08$ & $\mathrm{NT}$ \\
\hline \multicolumn{5}{c}{ NT-not tested. }
\end{tabular}

\subsection{Molecular Docking Studies}

The synthesized compounds were subjected to molecular docking studies [15] with the DNA topoisomerase IV [21-23] and anaplastic lymphoma kinase [24] receptors in order to rationalize the biological studies. The docking study of the synthesized compounds was performed using AutoDock Tools (ADT) version 1.5.6 and AutoDock version 4.2.5.1 docking program [25,26] with the crystal structure of DNA topoisomerase IV (PDB ID: 4EMV) and anaplastic lymphoma kinase (PDB ID: 2XP2) [27]. The conformations of the docked ligands with receptors were evaluated in terms of energy, hydrogen bonding, polar, and hydrophobic interactions. The free energy of binding (FEB) was estimated for all the synthesized compounds $\mathbf{5 a}-\mathbf{1}$ and listed in Table 6 .

Table 6. Binding energy of synthesized compounds.

\begin{tabular}{ccc}
\hline \multirow{2}{*}{ Compound } & \multicolumn{2}{c}{ Binding Energy (kcal/mol) ${ }^{\mathbf{a}}$} \\
\cline { 2 - 3 } & DNA Topoisomerase IV (4EMV) & Anaplastic Lymphoma Kinase (2XP2) \\
\hline $\mathbf{5 a}$ & -7.31 & -6.55 \\
$\mathbf{5 b}$ & -8.64 & $\mathrm{NC}$ \\
$\mathbf{5} \mathbf{5}$ & -8.76 & $\mathrm{NC}$ \\
$\mathbf{5 d}$ & -8.84 & $\mathrm{NC}$ \\
$\mathbf{5 e}$ & -7.63 & -7.79 \\
$\mathbf{5 f}$ & -8.93 & $\mathrm{NC}$ \\
$\mathbf{5 g}$ & -8.06 & -8.12 \\
$\mathbf{5} \mathbf{5}$ & -7.24 & -7.10 \\
$\mathbf{5 i}$ & -8.98 & -8.28 \\
$\mathbf{5} \mathbf{5}$ & -7.63 & -8.72 \\
$\mathbf{5}$ & -8.75 & $\mathrm{NC}$ \\
$\mathbf{5}$ & -7.71 & $\mathrm{NC}$ \\
$\mathrm{CL}$ & -9.80 & -8.42 \\
\hline
\end{tabular}

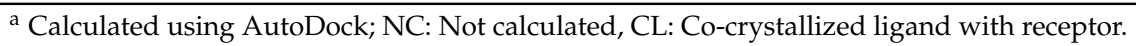


The molecular docking experiment established that the synthesized compounds $5 \mathbf{a}-\mathbf{1}$ had a good free energy of binding with the 4EMV receptor. These results revealed that the compounds 5a-1 exhibit free energy of binding values from -7.24 to $-8.98 \mathrm{kcal} / \mathrm{mol}$. Interestingly, compound $5 \mathrm{f}$ exhibited good binding with the $4 \mathrm{EMV}$ receptor with a binding energy of $-8.93 \mathrm{kcal} / \mathrm{mol}$. In $5 \mathrm{f}, \mathrm{N}-\mathrm{CH}_{3}$ formed a hydrogen bond with the H-O of THR-172 with the bond length of $2.8 \AA$. In addition, nitrogens of triazole interacted with the GLY-82 and formed the polar interactions. Furthermore, compound $5 \mathbf{f}$ exhibited a hydrophobic interaction with ASN-51, GLU-55, GLY-82, HIS-120, and THR-172 amino acids. Binding interaction of the compound $\mathbf{5 f}$ with the $4 \mathrm{EMV}$ receptor is shown in Figure 4.
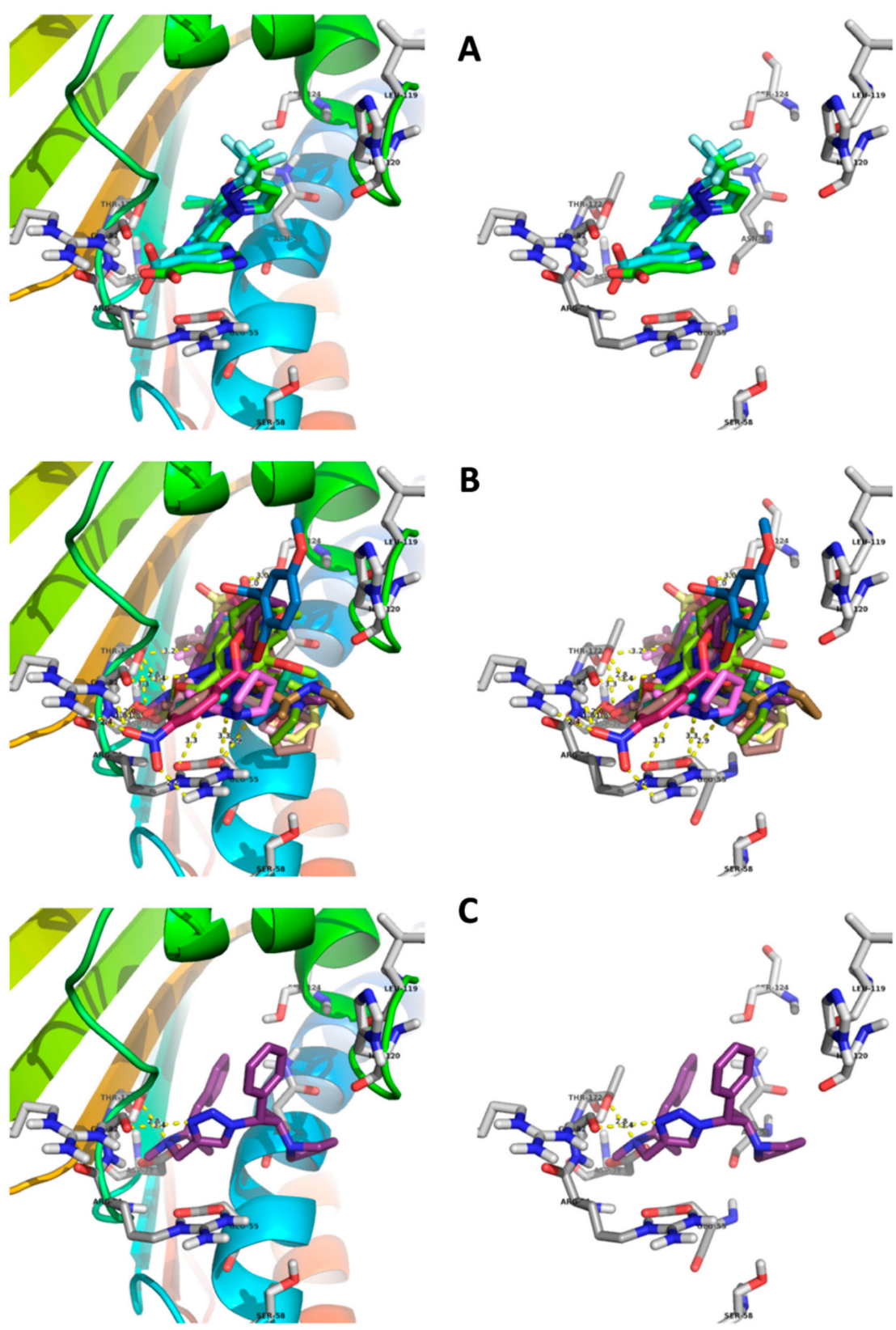

Figure 4. Molecular docking with 4EMV receptor: (A) method validation using a crystallized and docked ligand, (B) docking mode of all the compounds, and (C) docking mode of $\mathbf{5 f}$.

Docking experiments of synthesized compounds with the 2XP2 (ALK tyrosine kinase receptor) receptor revealed that all the docked compounds bind with the receptor and exhibits free energy of binding value from -6.55 to $-8.72 \mathrm{kcal} / \mathrm{mol}$. Compounds $5 \mathrm{a}-\mathbf{1}$ interacted with the active site amino acids 
of 2XP2 namely ARG-1120, LEU-1122, GLY-1123, VAL-1130, GLU-1132, ALA-1148, LYS-1150, LEU-1196, GLU-1197, LEU-1198, MET-1199, ALA-1200, GLY-1201, GLY-1202, ASP-1203, SER-1206, PHE-1207, GLU-1210, ARG-1253, ASN-1254, CYS-1255, LEU-1256, GLY-1269, and ASP-1270. Compound 5g exhibited better binding with the 2XP2 receptor, displaying a binding energy of $-8.12 \mathrm{kcal} / \mathrm{mol}$. In compound $5 \mathrm{~g}$, two oxygens of $\mathrm{NO}_{2}$ interacted with the $\mathrm{N}-\mathrm{H}$ of LYS-1150 and formed two hydrogen bonds with the bond lengths of $1.6 \AA$ and $2.8 \AA$. In addition, $\mathrm{C}=\mathrm{O}$ formed a polar interaction with the GLU-1197 amino acid. Furthermore, compound 5g exhibited a hydrophobic interaction with the LEU-1122, ALA-1148, LYS-1150, LEU-1196, LEU-1198, ALA-1200, GLY-1201, GLY-1202, and LEU-1256 amino acids. The binding interaction of the compound $\mathbf{5 g}$ with the 2 XP2 receptor is shown in Figure 5.
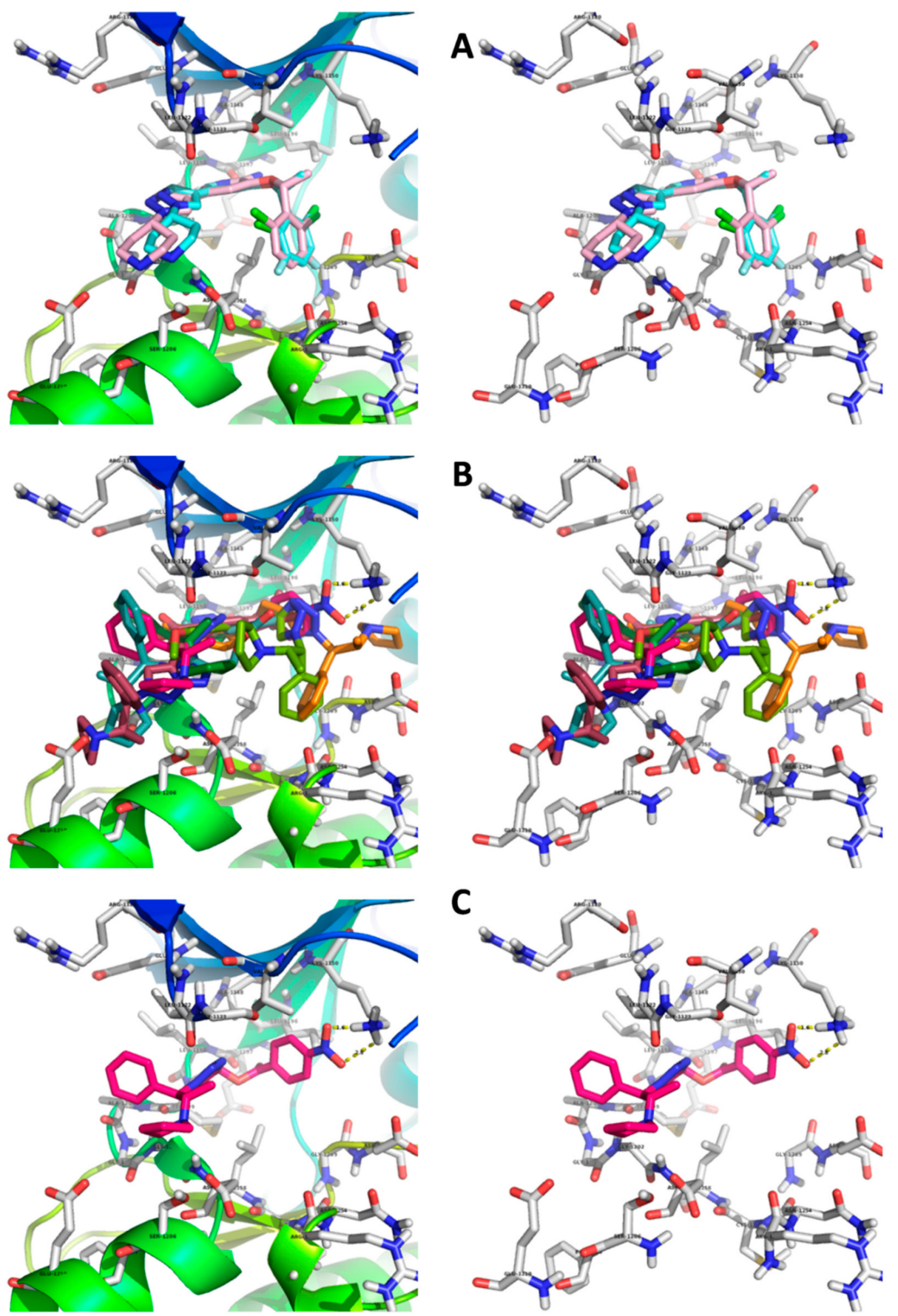

Figure 5. Molecular docking with the 2XP2 receptor: (A) method validation using a crystallized and docked ligand, (B) docking mode of all the compounds, and (C) docking mode of $\mathbf{5 g}$. 


\section{Materials and Methods}

Synthesis of 1-((1R,2R)-1-chloro-1-phenylpropan-2-yl)pyrrolidine hydrochloride 2: Thionyl chloride $(49.3 \mathrm{~g}, 0.41 \mathrm{~mol})$ was slowly added to the mixture of pyrrolidinylnorephedrine hydrochloride $(50 \mathrm{~g}$, $0.21 \mathrm{~mol})$ and chloroform $(200 \mathrm{~mL})$ at $25-30^{\circ} \mathrm{C}$. The mass was heated to $60-65^{\circ} \mathrm{C}$ and refluxed for $3 \mathrm{~h}$. Progress of the reaction was monitored using TLC (Thin Layer Chromatography) (mobile phase: 100\% dichloromethane). After completion of the reaction, chloroform and unreacted thionyl chloride were distilled out completely. The mass was stirred with $200 \mathrm{~mL}$ of acetone for $30 \mathrm{~min}$, and the obtained solid was filtered and dried under vacuum at $65^{\circ} \mathrm{C}$; a white crystalline solid was produced, weight $38 \mathrm{~g}(70 \%)$.

Synthesis of 1-((1S,2R)-1-azido-1-phenylpropan-2-yl)pyrrolidine 3: Compound 2 (25 g, $0.096 \mathrm{~mol})$ was added in lots to the solution of sodium azide $(9.4 \mathrm{~g}, 0.14 \mathrm{~mol}, 1.5 \mathrm{~mol}$ equiv.) in dimethylformamide $(100 \mathrm{~mL})$ at $20-25^{\circ} \mathrm{C}$. The contents were stirred at $20-25^{\circ} \mathrm{C}$ for $12 \mathrm{~h}$. Progress of reaction was monitored via watching the formation of sodium chloride as a white precipitate during the stirring. Progress of the reaction was further monitored using TLC (mobile phase: 100\% dichloromethane). After completion of the reaction, the mass was poured into ice water $(300 \mathrm{~mL})$ and basified with sodium hydroxide $(\mathrm{pH}$ about 10). Ethyl acetate (100 mL) was added, stirred for $10 \mathrm{~min}$, and the organic layer was separated and dried over sodium sulfate. Ethyl acetate was distilled off completely using a rotavap at $60^{\circ} \mathrm{C}$ to get the azide 3 as a syrupy mass and it was preserved in a refrigerator. It was used as such in the next step without any further purification. Weight of the azide 3: $15 \mathrm{~g}(68 \%)$.

Preparation of catalyst $\mathrm{CuI} / \mathrm{Al}_{2} \mathrm{O}_{3}$ : Neutral alumina (100g) and copper iodide (10g) and methanol $(300 \mathrm{~mL})$ were mixed and heated for $1.0 \mathrm{~h}$ at $55-60^{\circ} \mathrm{C}$. Methanol was distilled off completely and the free-flowing white powder was dried at $75^{\circ} \mathrm{C}$ for $6 \mathrm{~h}$. The obtained catalyst was stored under nitrogen.

\subsection{Pharmacological Activities}

Antimicrobial activity was carried out as described previously [19,20]. Briefly, $20 \mathrm{~mL}$ of sterile Mueller Hinton agar (MHA) was poured in the petri plates and kept for solidification. After solidification, the test cultures were swabbed on the top of the media and kept for $10 \mathrm{~min}$ to dry. The required concentration ( $1 \mathrm{mg} /$ well) of synthesized compounds $5 \mathrm{a}-\mathbf{1}$ was added to each well and left for $30 \mathrm{~min}$ at RT for compound diffusion. Ketoconazole (fungi) and streptomycin (bacteria) used for positive controls. The zone of inhibition was recorded in $\mathrm{mm}$ and the experiment was repeated twice.

\subsection{Minimum Inhibitory Concentration (MIC)}

The MIC experiment was carried out according to the standard reference methods $[19,20]$. Briefly, the required concentrations of synthesized compounds $5 \mathbf{a}-\mathbf{1}$ were dissolved in DMSO (Dimethylsulfoxide) in concentrations of $500 \mu \mathrm{g} / \mathrm{mL}, 250 \mu \mathrm{g} / \mathrm{mL}, 125 \mu \mathrm{g} / \mathrm{mL}, 62.5 \mu \mathrm{g} / \mathrm{mL}, 31.25 \mu \mathrm{g} / \mathrm{mL}$, $15.6 \mu \mathrm{g} / \mathrm{mL}$, and $0.78 \mu \mathrm{g} / \mathrm{mL}$. An inoculum of $100 \mu \mathrm{L}$ from each well (96-well plate) was inoculated. For the positive control, ketoconazole (fungi) and streptomycin (bacteria) was used. The MIC values for the tested bacteria were identified as the lowest inhibiting concentration of compound on the agar plate in visual growth.

\subsection{Cytotoxicity Properties}

The cytotoxic study was carried out as reported previously [15,21]. Briefly, IMR90, HepG-2, and A549 cells were grown in DMEM (Dulbecco's Modified Eagle Medium) that contained 10\% fetal bovine serum and $1 \%$ antibiotics. A total of $15 \times 10^{3}$ cells/well were seeded in 96-well plates and incubated under humidified conditions. Cells were treated with varying concentrations of synthesized triazoles for $24 \mathrm{~h}$. After a $24 \mathrm{~h}$ treatment, $20 \mu \mathrm{L}$ aqueous one solution reagent was added to each well and incubated for 3-4 h under a humidified condition. For IMR90 cells, MTT (MTT = 3-(4,5-dimethyl-2-thiazolyl)-2,5-diphenyl-2H-tetrazolium bromide) $(5 \mathrm{mg} / \mathrm{mL})$ was added and incubated for $3-4 \mathrm{~h}$ in the dark. After incubation, $100 \mu \mathrm{L}$ of a $10 \%$ SDS (Sodium Dodecyl Sulfate) 
solution $(0.01 \% \mathrm{HCl})$ was added to each well. The data was taken using an ELISA (enzyme-linked immunosorbent assay) reader at the absorbance of $490 \mathrm{~nm}$ for HepG-2 and A549 cells and $570 \mathrm{~nm}$ for IMR90 cells. The cell death was calculated using the following formula: Inhibition $(\%)=((\mathrm{A}-\mathrm{B}) / \mathrm{A}) \times$ 100 (A—control group, B-treated group).

\subsection{General Procedure for the Synthesis of $\beta$-pyrrolidino-1,2,3-triazoles 5a-1:}

Propargyl alcohol $4 \mathbf{a}(0.53 \mathrm{~g}, 9.5 \mathrm{mmol})$ was added to a solution of azide $3(2.0 \mathrm{~g}, 8.6 \mathrm{mmol})$ taken in a mixture of solvents ( $30 \mathrm{~mL}-\mathrm{MeOH} / \mathrm{THF}$ (Tetrahydrofuran)/water in equal amounts) followed by diisopropylethylamine $(1.35 \mathrm{~g}, 10.4 \mathrm{mmol})$ and catalyst $\left(\mathrm{CuI} / \mathrm{Al}_{2} \mathrm{O}_{3} 5 \mathrm{~mol} \%\right)$ at $20-25^{\circ} \mathrm{C}$ for $8-10 \mathrm{~h}$. Completion of the reaction was monitored using TLC (mobile phase: $10 \%$ methanol in dichloromethane). After completion of the reaction, the catalyst was removed via filtration and preserved for recycling. The filtrate was concentrated in a rotavap to remove the solvents. Ethyl acetate $(50 \mathrm{~mL})$ was added to the concentrated mass and the organic layer was separated. The organic layer was washed with water $(20 \mathrm{~mL})$, dried over sodium sulfate, and completely concentrated to produce a semi-solid. The semi-solid was triturated with acetone $(5 \mathrm{~mL})$, filtered, and dried at $60{ }^{\circ} \mathrm{C}$ under vacuum. This produced compound $5 \mathbf{a}$ as a brown solid, weight $2.36 \mathrm{~g}(95 \%)$. The method as mentioned above was used to make compound $5 \mathbf{b}-\mathbf{1}$ using terminal alkynes $4 \mathbf{b}-\mathbf{1}$ instead of $4 \mathbf{a}$.

(1R,2S)-1-(1-(1-Phenyl-2-(pyrrolidin-1-yl)propyl)-1H-1,2,3-triazol-4-yl)methanol (5a)

Pale brown solid, yield $91 \%$, MP: $160-161{ }^{\circ} \mathrm{C}$, IR $\left(\mathrm{KBr}, \mathrm{cm}^{-1}\right)$ : 3252, 1354, 1009, 905, and 760; ${ }^{1} \mathrm{H}-\mathrm{NMR}\left(500 \mathrm{MHz}, \mathrm{CDCl}_{3}\right) ; \delta_{\mathrm{H}}(\mathrm{ppm}) 0.94\left(3 \mathrm{H}, \mathrm{d}, J=6.6 \mathrm{~Hz}, \mathrm{CH}_{3}\right), 1.63\left(4 \mathrm{H}, \mathrm{m}, \mathrm{C}-\mathrm{CH}_{2}-\mathrm{CH}_{2}-\mathrm{C}\right)$, 2.53-2.63 $\left(4 \mathrm{H}, \mathrm{m}, \mathrm{CH}_{2}-\mathrm{N}-\mathrm{CH}_{2}\right), 3.88-3.92\left(1 \mathrm{H}, \mathrm{m}, \mathrm{N}-\mathrm{CH}-\mathrm{C} \underline{\mathrm{H}}-\mathrm{CH}_{3}\right), 4.76\left(2 \mathrm{H}, \mathrm{s}, \mathrm{CH}_{2}-\mathrm{O}\right), 5.58(1 \mathrm{H}$, $\left.\mathrm{d}, J=10.0 \mathrm{~Hz}, \mathrm{C} \underline{\mathrm{H}}-\mathrm{CH}-\mathrm{CH}_{3}\right), 7.27-7.70\left(6 \mathrm{H}, \mathrm{m}\right.$, aromatic); ${ }^{13} \mathrm{C}-\mathrm{NMR}\left(125 \mathrm{MHz}, \mathrm{DMSO}-d_{6}\right) ; \delta_{\mathrm{C}}$ (ppm) $11.65\left(\mathrm{CH}_{3}\right), 23.68\left(\mathrm{C}_{3} \& \mathrm{C}_{4}\right.$ carbons of pyrrolidinyl ring $), 48.19\left(\mathrm{C}_{2} \& \mathrm{C}_{5}\right.$ carbons of pyrrolidinyl ring $)$, $56.7\left(\mathrm{CH}-\mathrm{CH}-\mathrm{CH}_{3}\right), 58.50\left(\underline{\mathrm{CH}}-\mathrm{CH}-\mathrm{CH}_{3}\right), 69.32\left(\mathrm{OCH}_{2}\right), 121.46,127.75,128.55,128.93,137.80$, and 148.19; ESI-MS: $m / z 287\left([\mathrm{M}+\mathrm{H}]^{+}, 100 \%\right)$; Anal. Calcd for $\mathrm{C}_{16} \mathrm{H}_{22} \mathrm{~N}_{4} \mathrm{O}: \mathrm{C}, 67.11 ; \mathrm{H}, 7.74 ; \mathrm{N}, 19.56$ Found C, 67.24; H, 7.86; N, 19.68 .

(1R,2S)-1-((1-(1-Phenyl-2-(pyrrolidin-1-yl)propyl)-1H-1,2,3-triazol-4-yl)methyl) cyclohexanol, (5b)

Brown solid, yield 84\%, MP: $137-138{ }^{\circ} \mathrm{C}$, IR $\left(\mathrm{KBr}, \mathrm{cm}^{-1}\right)$ : 3375, 1350, 1001, 982, and 748; ${ }^{1} \mathrm{H}-\mathrm{NMR}$ $\left(500 \mathrm{MHz}, \mathrm{CDCl}_{3}\right) ; \delta_{\mathrm{H}}(\mathrm{ppm}) 1.00\left(3 \mathrm{H}, \mathrm{d}, J=6.6 \mathrm{~Hz}, \mathrm{CH}_{3}\right), 1.18-1.32\left(2 \mathrm{H}, \mathrm{m}\right.$, five $\mathrm{CH}_{2}$ of cycloxyl ring at $\left.\mathrm{C}_{4}\right), 1.35-1.52\left(4 \mathrm{H}, \mathrm{m}\right.$, two $\mathrm{CH}_{2}{ }^{\prime}$ s of cycloxyl ring at $\left.\mathrm{C}_{4} \& \mathrm{C}_{4}\right), 1.66-1.84\left(4 \mathrm{H}, \mathrm{m}\right.$, two $\mathrm{CH}_{2}{ }^{\prime} \mathrm{s}$ of pyrrolidinyl ring at $\left.\mathrm{C}_{3} \& \mathrm{C}_{4}\right), 1.86\left(2 \mathrm{H}, \mathrm{s}, \mathrm{CH}_{2}\right.$ attached to triazole ring), 1.98-2.21 $(4 \mathrm{H}, \mathrm{m}$, two $\mathrm{CH}_{2}{ }^{\prime}$ s of pyrrolidinyl ring at $\left.\mathrm{C}_{2} \& \mathrm{C}_{5}\right), 2.32\left(1 \mathrm{H}, \mathrm{m}, \mathrm{CH}-\mathrm{CH}_{3}\right), 2.54-2.63\left(4 \mathrm{H}, \mathrm{m}\right.$, two $\mathrm{CH}_{2}{ }^{\prime}$ s of cycloxyl ring at $\left.\mathrm{C}_{2} \& \mathrm{C}_{6}\right), 3.93(1 \mathrm{H}, \mathrm{s}, \mathrm{OH}), 5.64\left(1 \mathrm{H}, \mathrm{m}, \mathrm{C}-\mathrm{H}-\mathrm{CH}-\mathrm{CH}_{3}\right), 7.23-7.59\left(6 \mathrm{H}, \mathrm{m}\right.$, aromatic); ${ }^{13} \mathrm{C}-\mathrm{NMR}$ $\left(125 \mathrm{MHz}, \mathrm{CDCl}_{3}\right) ; \delta_{\mathrm{C}}(\mathrm{ppm}) 11.23\left(\mathrm{CH}_{3}\right), 22.11\left(\mathrm{C}_{4}\right.$ carbon of cyclohexyl ring), $23.58\left(\mathrm{C}_{3} \& \mathrm{C}_{4}\right.$ carbon of pyrrolidinyl ring), $25.41 \& 25.93\left(C_{3} \& C_{5}\right.$ carbons of cyclohexyl ring), $26.77\left(C_{2} \& C_{6}\right.$ carbons of cyclohexyl ring), $48.26\left(\mathrm{C}_{2} \& \mathrm{C}_{5}\right.$ carbons of pyrrolidinyl ring), $49.71\left(\underline{\mathrm{C}} \mathrm{H}-\mathrm{CH}_{3}\right), 51.22\left(\underline{\mathrm{CH}}-\mathrm{CH}-\mathrm{CH}_{3}\right)$, 66.50 ( $\mathrm{C}_{1}$ carbon of cyclohexyl ring $), 120.48,124.46,127.66,128.69,135.46$, and 148.91; ESI-MS: $\mathrm{m} / \mathrm{z} 369$ $\left([\mathrm{M}+\mathrm{H}]^{+}, 100 \%\right)$; Anal. Calcd for $\mathrm{C}_{22} \mathrm{H}_{32} \mathrm{~N}_{4} \mathrm{O}: \mathrm{C}, 71.70 ; \mathrm{H}, 8.75 ; \mathrm{N}, 15.20$; Found $\mathrm{C}, 71.81 ; \mathrm{H}, 8.87$; $\mathrm{N}, 15.32$.

(1R,2S)- (1-(1-Phenyl-2-(pyrrolidin-1-yl)propyl)-1H-1,2,3-triazol-4-yl)methyl cinnamate, (5c)

Brownish yellow solid, yield 88\%, MP: $140-141^{\circ} \mathrm{C}$, IR $\left(\mathrm{KBr}, \mathrm{cm}^{-1}\right)$ : 1713, 1599, 1578, 1369, 1275, $1011,978,847$, and $775 ;{ }^{1} \mathrm{H}-\mathrm{NMR}\left(500 \mathrm{MHz}, \mathrm{CDCl}_{3}\right) ; \delta_{\mathrm{H}}(\mathrm{ppm}) 0.95\left(3 \mathrm{H}, \mathrm{d}, J=6.5 \mathrm{~Hz}, \mathrm{CH}_{3}\right), 1.77-2.01$ $\left(4 \mathrm{H}, \mathrm{m}\right.$, two $\mathrm{CH}_{2}{ }^{\prime} \mathrm{s}$ of pyrrolidinyl ring at $\left.\mathrm{C}_{3} \& \mathrm{C}_{4}\right), 2.48-2.59\left(4 \mathrm{H}, \mathrm{m}\right.$, two $\mathrm{CH}_{2}{ }^{\prime}$ s of pyrrolidinyl ring at $\left.\mathrm{C}_{2} \& \mathrm{C}_{5}\right), 3.81-3.87\left(2 \mathrm{H}, \mathrm{m}, \mathrm{OCH}_{2}\right), 5.52-5.54\left(1 \mathrm{H}, \mathrm{m}, \mathrm{N}-\mathrm{C} \underline{\mathrm{H}}-\mathrm{CH}_{3}\right), 6.45(1 \mathrm{H}, \mathrm{d}, J=16 \mathrm{~Hz}$, C $\left.\underline{\mathrm{H}}-\mathrm{CH}-\mathrm{CH}_{3}\right), 7.28-7.65\left(12 \mathrm{H}, \mathrm{m}\right.$, aromatic); ${ }^{13} \mathrm{C}-\mathrm{NMR}\left(100 \mathrm{MHz}, \mathrm{CDCl}_{3}\right) ; \delta_{\mathrm{C}}(\mathrm{ppm}) 11.91\left(\mathrm{CH}_{3}\right), 22.14$ ( $\mathrm{C}_{3} \& \mathrm{C}_{4}$ carbon of pyrrolidinyl ring), 48.12 ( $\mathrm{C}_{2} \& \mathrm{C}_{5}$ carbons of pyrrolidinyl ring), $48.45\left(\underline{\mathrm{C}} \mathrm{H}-\mathrm{CH}_{3}\right)$, $58.65\left(\mathrm{C} H-\mathrm{CH}-\mathrm{CH}_{3}\right), 69.55\left(\mathrm{O}-\mathrm{CH}_{2}\right), 112.04,116.30,119.29,124.25,127.84,128.99,132.25,135.02,141.83$, 
158.54, and 169.30 (ester carbonyl); ESI-MS: $m / z 417\left([\mathrm{M}+\mathrm{H}]^{+}, 100 \%\right.$ ); Anal. Calcd for $\mathrm{C}_{25} \mathrm{H}_{28} \mathrm{~N}_{4} \mathrm{O}_{2}$ : C, 72.09; H, 6.78; N, 13.45 Found C, 72.18; H, 6.86; N, 13.52 .

(1R,2S)- (1-(1-Phenyl-2-(pyrrolidin-1-yl)propyl)-1H-1,2,3-triazol-4-yl)methyl benzoate, (5d)

Pale brown solid, yield 75\%, MP: $129-130^{\circ} \mathrm{C}$, IR $\left(\mathrm{KBr}, \mathrm{cm}^{-1}\right)$ : 1730, 1589, 1568, 1331, 1286, 1018, 947, 852, and 773; ${ }^{1} \mathrm{H}-\mathrm{NMR}\left(500 \mathrm{MHz}, \mathrm{CDCl}_{3}\right) ; \delta_{\mathrm{H}}(\mathrm{ppm}) 0.92\left(3 \mathrm{H}, \mathrm{d}, J=3.0 \mathrm{~Hz}, \mathrm{CH}_{3}\right), 1.58-1.66(4 \mathrm{H}$, $\mathrm{m}$, two $\mathrm{CH}_{2}{ }^{\prime}$ s of pyrrolidinyl ring at $\left.\mathrm{C}_{3} \& \mathrm{C}_{4}\right), 2.51-2.59\left(4 \mathrm{H}, \mathrm{m}\right.$, two $\mathrm{CH}_{2}{ }^{\prime} \mathrm{s}$ of pyrrolidinyl ring at $\left.\mathrm{C}_{2} \& \mathrm{C}_{5}\right), 5.47\left(2 \mathrm{H}, \mathrm{s}, \mathrm{OCH}_{2}\right), 5.54-5.56\left(1 \mathrm{H}, \mathrm{m}, \mathrm{N}-\mathrm{C} \underline{\mathrm{H}}-\mathrm{CH}_{3}\right), 6.86-6.68(1 \mathrm{H}, \mathrm{d}$ of d, J = 8.8 \& $3.1 \mathrm{~Hz}$, $\mathrm{C}$ H-CH-CH 3$), 7.27-7.89\left(11 \mathrm{H}, \mathrm{m}\right.$, aromatic); ${ }^{13} \mathrm{C}-\mathrm{NMR}\left(500 \mathrm{MHz}, \mathrm{CDCl}_{3}\right) ; \delta_{\mathrm{C}}(\mathrm{ppm}) 11.93\left(\mathrm{CH}_{3}\right), 23.60$ ( $\mathrm{C}_{3} \& \mathrm{C}_{4}$ carbon of pyrrolidinyl ring), 48.45 ( $\mathrm{C}_{2} \& \mathrm{C}_{5}$ carbons of pyrrolidinyl ring), $55.68\left(\underline{\mathrm{C}} \mathrm{H}-\mathrm{CH}_{3}\right)$, $58.91\left(\mathrm{C} H-\mathrm{CH}-\mathrm{CH}_{3}\right), 69.09\left(\mathrm{O}-\mathrm{CH}_{2}\right), 112.02,116.25,119.29,124.25,127.84,128.68,128.99,132.25$, 137.46, 141.84, 158.68, and 166.80 (ester carbonyl); ESI-MS: $m / z 391\left([\mathrm{M}+\mathrm{H}]^{+}, 100 \%\right)$; Anal. Calcd for $\mathrm{C}_{23} \mathrm{H}_{26} \mathrm{~N}_{4} \mathrm{O}_{2}: \mathrm{C}, 70.75 ; \mathrm{H}, 6.71 ; \mathrm{N}, 14.35$. Found $\mathrm{C}, 70.86 ; \mathrm{H}, 6.80 ; \mathrm{N}, 14.47$.

(1R,2S)- (1-(1-Phenyl-2-(pyrrolidin-1-yl)propyl)-1H-1,2,3-triazol-4-yl)methyl-2-bromo-5-methoxy benzoate, (5e)

Pale brown solid, yield $92 \%$, MP: $111-112{ }^{\circ} \mathrm{C}$, IR $\left(\mathrm{KBr}, \mathrm{cm}^{-1}\right)$ : 1725, 1589, 1570, 1315, 1286, 1018 , 947, and 852; ${ }^{1} \mathrm{H}-\mathrm{NMR}\left(400 \mathrm{MHz}, \mathrm{DMSO}-d_{6}\right) ; \delta_{\mathrm{H}}(\mathrm{ppm}) 0.99-1.04\left(3 \mathrm{H}, \mathrm{m}, \mathrm{CH}_{3}\right), 1.57-1.80(4 \mathrm{H}, \mathrm{m}$, two $\mathrm{CH}_{2}$ 's of pyrrolidinyl ring at $\left.\mathrm{C}_{3} \& \mathrm{C}_{4}\right), 2.56-2.75\left(4 \mathrm{H}, \mathrm{m}\right.$, two $\mathrm{CH}_{2}$ 's of pyrrolidinyl ring at $\mathrm{C}_{2}$ \& $\left.\mathrm{C}_{5}\right), 3.80\left(3 \mathrm{H}, \mathrm{s}, \mathrm{OCH}_{3}\right) 5.48\left(2 \mathrm{H}, \mathrm{s}, \mathrm{OCH}_{2}\right), 5.78\left(1 \mathrm{H}, \mathrm{m}, \mathrm{N}-\mathrm{C} \underline{\mathrm{H}}-\mathrm{CH}_{3}\right), 6.88-6.91(1 \mathrm{H}, \mathrm{dd}, J=8.8$ \& $\left.3.1 \mathrm{~Hz}, \mathrm{C}-\mathrm{H}-\mathrm{CH}-\mathrm{CH}_{3}\right), 7.28-7.94\left(9 \mathrm{H}, \mathrm{m}\right.$, aromatic); ${ }^{13} \mathrm{C}-\mathrm{NMR}\left(100 \mathrm{MHz}, \mathrm{DMSO}-d_{6}\right) ; \delta_{\mathrm{C}}(\mathrm{ppm}) 11.31$ $\left(\mathrm{CH}_{3}\right), 23.70\left(\mathrm{CH}-\mathrm{CH}-\mathrm{CH}_{3}\right), 47.94\left(\mathrm{C}_{3} \& \mathrm{C}_{4}\right.$ carbons of pyrrolidinyl ring $), 55.69\left(\mathrm{C}_{2} \& \mathrm{C}_{5}\right.$ carbons of pyrrolidinyl ring), $58.57\left(\mathrm{CH}-\mathrm{CH}-\mathrm{CH}_{3}\right), 58.96\left(\mathrm{OCH}_{3}\right), 69.49\left(\mathrm{OCH}_{2}\right), 112.06,116.29,119.31,124.00$, $127.81,128.57,128.93,132.31,135.01,137.67,141.65,158.57$, and 165.83 (ester carbonyl); ESI-MS: $m / z 499$ and $501\left([\mathrm{M}+\mathrm{H}]^{+}, 100 \%\right)$, in the ratio of 1:1); Anal. Calcd for $\mathrm{C}_{24} \mathrm{H}_{27} \mathrm{BrN}_{4} \mathrm{O}_{3}: \mathrm{C}, 57.72 ; \mathrm{H}, 5.45 ; \mathrm{N}$, 11.22 Found C, 57.84; H, 5.52; N, 11.29.

(1R,2S)-N-Methyl-1-phenyl-N-((1-(1-phenyl-2-(pyrrolidin-1-yl)propyl)-1H-1,2,3-triazol-4-yl)methyl)propan-2amine, (5f)

Brown solid, yield $75 \%$, MP: $118-119{ }^{\circ} \mathrm{C}$, IR $\left(\mathrm{KBr}, \mathrm{cm}^{-1}\right)$ : 1551, 1495, 1366, 1258, 1026, 959, 849, and 741; ${ }^{1} \mathrm{H}-\mathrm{NMR}\left(400 \mathrm{MHz}, \mathrm{DMSO}-d_{6}\right) ; \delta_{\mathrm{H}}(\mathrm{ppm}) 1.03\left(3 \mathrm{H}, \mathrm{d}, J=6.4 \mathrm{~Hz}, \mathrm{CH}_{3}\right), 1.26(3 \mathrm{H}, \mathrm{m}$, $\left.\mathrm{CH}_{3}\right), 1.54-1.59\left(4 \mathrm{H}, \mathrm{m}\right.$, two $\mathrm{CH}_{2}{ }^{\prime}$ s of pyrrolidinyl ring at $\left.\mathrm{C}_{3} \& \mathrm{C}_{4}\right), 2.29-2.30\left(4 \mathrm{H}, \mathrm{m}\right.$, two $\mathrm{CH}_{2}{ }^{\prime} \mathrm{s}$ of pyrrolidinyl ring at $\left.\mathrm{C}_{2} \& \mathrm{C}_{5}\right), 2.43-2.48(2 \mathrm{H}, \mathrm{m}), 2.56-2.58\left(2 \mathrm{H}, \mathrm{d}, J=7.0 \mathrm{~Hz}\right.$. $\left.\mathrm{CH}-\mathrm{C}_{2}\right), 2.95-2.97(2 \mathrm{H}$, $\mathrm{m}), 3.82\left(3 \mathrm{H}, \mathrm{s}, \mathrm{N}-\mathrm{CH}_{3}\right), 5.45\left(1 \mathrm{H}, \mathrm{d}, J=9.8 \mathrm{~Hz}, \mathrm{CH}-\mathrm{CH}-\mathrm{CH}_{3}\right), 7.08-7.47(11 \mathrm{H}, \mathrm{m}$, aromatic $) ;{ }^{13} \mathrm{C}-\mathrm{NMR}$ $\left(100 \mathrm{MHz}, \mathrm{DMSO}-d_{6}\right) ; \delta_{\mathrm{C}}(\mathrm{ppm}) 10.92 \& 11.37\left(\mathrm{CH}_{2}-\mathrm{CH}-\mathrm{CH}_{3} \& \mathrm{CH}-\mathrm{CH}-\mathrm{CH}_{3}\right), 30.28\left(\underline{\mathrm{CH}}_{2}-\mathrm{Ph}\right), 36.02$ $\left(\mathrm{CH}-\mathrm{CH}-\mathrm{CH}_{3}\right), 38.41\left(\mathrm{CH}_{2}-\underline{\mathrm{C}} \mathrm{H}-\mathrm{CH}_{3}\right), 47.95\left(\mathrm{C}_{3} \& \mathrm{C}_{4}\right.$ carbons of pyrrolidinyl ring $), 48.97\left(\mathrm{C}_{2} \& \mathrm{C}_{5}\right.$ carbons of pyrrolidinyl ring), $58.55\left(\underline{\mathrm{CH}}-\mathrm{CH}-\mathrm{CH}_{3}\right), 59.57\left(\mathrm{~N}-\mathrm{CH}_{2}\right), 115.27,115.99,124.06,126.29,127.94$ 128.38, 129.90, 137.59, 142.27, and 159.02; ESI-MS: $\mathrm{m} / z 418\left([\mathrm{M}+\mathrm{H}]^{+}, 100 \%\right)$; Anal. Calcd for $\mathrm{C}_{26} \mathrm{H}_{35} \mathrm{~N}_{5}$ : C, 74.78; H, 8.45; N, 16.77 Found C, 74.92; H, 8.52; N, 16.83 .

(1R,2S)- (1-(1-Phenyl-2-(pyrrolidin-1-yl)propyl)-1H-1,2,3-triazol-4-yl)methyl 4-nitrobenzoate, (5g)

Yellowish brown powder, yield 69\%, MP: $137-138^{\circ} \mathrm{C}, \mathrm{IR}\left(\mathrm{KBr}, \mathrm{cm}^{-1}\right): 1722,1607,1528,1348,1271$, $1015,937,854$, and 787; ${ }^{1} \mathrm{H}-\mathrm{NMR}\left(400 \mathrm{MHz}, \mathrm{DMSO}-d_{6}\right) ; \delta_{\mathrm{H}}(\mathrm{ppm}) 1.01\left(3 \mathrm{H}, \mathrm{d}, J=5.9 \mathrm{~Hz}, \mathrm{CH}_{3}\right), 1.58-1.71$ $\left(4 \mathrm{H}, \mathrm{m}\right.$, two $\mathrm{CH}_{2}{ }^{\prime} \mathrm{s}$ of pyrrolidinyl ring at $\left.\mathrm{C}_{3} \& \mathrm{C}_{4}\right), 2.57-2.67\left(4 \mathrm{H}, \mathrm{m}\right.$, two $\mathrm{CH}_{2}{ }^{\prime} \mathrm{s}$ of pyrrolidinyl ring at $\left.\mathrm{C}_{2} \& \mathrm{C}_{5}\right), 4.00\left(1 \mathrm{H}, \mathrm{m}, \mathrm{C} \underline{\mathrm{H}}-\mathrm{CH}_{3}\right), 5.52\left(2 \mathrm{H}, \mathrm{s}, \mathrm{OCH}_{2}\right), 5.71\left(1 \mathrm{H}, \mathrm{brs}, \mathrm{C} \underline{\mathrm{H}}-\mathrm{CH}-\mathrm{CH}_{3}\right), 7.28-8.29$

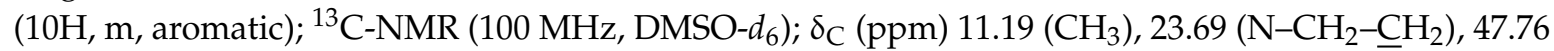
$\left(\mathrm{N}-\mathrm{CH}_{2}-\mathrm{CH}_{2}\right), 58.30\left(\mathrm{~N}-\mathrm{CH}-\mathrm{CH}_{3}\right), 59.03(\mathrm{~N}-\mathrm{C} H-\mathrm{Ph}), 69.96\left(\mathrm{OCH}_{2}\right), 123.50,124.01,127.888,128.62$, $128.94,130.85,135.30,137.57,141.16,150.63$, and 164.57 (carbon of ester carbonyl); ESI-MS: $\mathrm{m} / \mathrm{z} 436$ $\left([\mathrm{M}+\mathrm{H}]^{+}, 100 \%\right)$; Anal. Calcd for $\mathrm{C}_{23} \mathrm{H}_{25} \mathrm{~N}_{5} \mathrm{O}_{4}: \mathrm{C}, 63.44 ; \mathrm{H}, 5.79 ; \mathrm{N}, 16.08$ Found $\mathrm{C}, 63.55 ; \mathrm{H}, 5.82$; $\mathrm{N}, 16.14$. 
(1R,2S)- (1-(1-Phenyl-2-(pyrrolidin-1-yl)propyl)-1H-1,2,3-triazol-4-yl)methyl-3,4-dimethoxy-benzoate, (5h)

Brown powder, yield $86 \%$, MP $108-109^{\circ} \mathrm{C}$, IR $\left(\mathrm{KBr}, \mathrm{cm}^{-1}\right)$ : 1701, 1599, 1514, 1385, 1271, 1020, 949, and $843 ;{ }^{1} \mathrm{H}-\mathrm{NMR}\left(400 \mathrm{MHz}, \mathrm{DMSO}-d_{6}\right) ; \delta_{\mathrm{H}}(\mathrm{ppm}) 1.02\left(3 \mathrm{H}, \mathrm{d}, J=1.2 \mathrm{~Hz}, \mathrm{CH}_{3}\right), 1.66\left(4 \mathrm{H}, \mathrm{m}\right.$, two $\mathrm{CH}_{2}{ }^{\prime} \mathrm{s}$ of pyrrolidinyl ring at $\left.\mathrm{C}_{3} \& \mathrm{C}_{4}\right), 2.59-2.61\left(4 \mathrm{H}, \mathrm{m}\right.$, two $\mathrm{CH}_{2}$ 's of pyrrolidinyl ring at $\left.\mathrm{C}_{2} \& \mathrm{C}_{5}\right), 3.92(3 \mathrm{H}$, $\left.\mathrm{s}, p-\mathrm{OCH}_{3}\right), 3.94\left(3 \mathrm{H}, \mathrm{s}, m-\mathrm{OCH}_{3}\right), 5.45\left(2 \mathrm{H}, \mathrm{s}, \mathrm{OCH}_{2}\right), 6.87(1 \mathrm{H}, \mathrm{m}), 6.89(1 \mathrm{H}, \mathrm{d}, J=8.5 \mathrm{~Hz}), 7.28-7.87$ $\left(9 \mathrm{H}, \mathrm{m}\right.$, aromatic); ${ }^{13} \mathrm{C}-\mathrm{NMR}\left(100 \mathrm{MHz}, \mathrm{DMSO}-d_{6}\right) ; \delta_{\mathrm{C}}(\mathrm{ppm}) 11.39\left(\mathrm{CH}_{3}\right), 13.85\left(\mathrm{~N}-\mathrm{CH}_{2}-\mathrm{CH}_{2}\right), 23.64$ $\left(\mathrm{N}-\mathrm{CH}_{2}-\mathrm{CH}_{2}\right), 47.86\left(\mathrm{~N}-\mathrm{CH}-\mathrm{CH}_{3}\right), 55.99(\mathrm{~N}-\mathrm{CH}-\mathrm{Ph}), 58.11\left(p-\mathrm{OCH}_{3}\right), 58.39\left(m-\mathrm{OCH}_{3}\right), 69.96\left(\mathrm{OCH}_{2}\right)$, $110.24,112.05,122.38,123.84,123.93,127.88,128.53,128.89,137.65,142.14,148.58,153.13$, and 166.24 (carbon of ester carbonyl); ESI-MS: $m / z 451\left([\mathrm{M}+\mathrm{H}]^{+}, 100 \%\right)$; Anal. Calcd for $\mathrm{C}_{25} \mathrm{H}_{30} \mathrm{~N}_{4} \mathrm{O}_{4}$ : C, 66.65; $\mathrm{H}$, $6.71 ; \mathrm{N}, 12.44$ Found $\mathrm{C}, 66.74 ; \mathrm{H}, 6.83 ; \mathrm{N}, 12.54$.

(1R,2S)- (1-(1-Phenyl-2-(pyrrolidin-1-yl)propyl)-1H-1,2,3-triazol-4-yl)methyl 4-tert-butyl benzoate, (5i)

Brown solid, yield $90 \%$, MP: $145-147^{\circ} \mathrm{C}$, IR $\left(\mathrm{KBr}, \mathrm{cm}^{-1}\right)$ : 1719, 1495, 1393, 1273, 1016, 951, 852, and $775 ;{ }^{1} \mathrm{H}-\mathrm{NMR}\left(400 \mathrm{MHz}, \mathrm{DMSO}-d_{6}\right) ; \delta_{\mathrm{H}}(\mathrm{ppm}) 0.93\left(3 \mathrm{H}, \mathrm{d}, J=16.3 \mathrm{~Hz}, \mathrm{CH}_{3}\right), 1.56(9 \mathrm{H}, \mathrm{s}$, tert-butyl), $2.37\left(4 \mathrm{H}, \mathrm{m}\right.$, two $\mathrm{CH}_{2}{ }^{\prime} \mathrm{s}$ of pyrrolidinyl ring at $\left.\mathrm{C}_{3} \& \mathrm{C}_{4}\right), 2.49-2.56\left(\mathrm{~m}, 4 \mathrm{H}\right.$ two $\mathrm{CH}_{2}$ 's of pyrrolidinyl ring at $\left.\mathrm{C}_{2} \& \mathrm{C}_{5}\right), 3.83-3.86\left(1 \mathrm{H}, \mathrm{m}, \mathrm{CH}-\mathrm{CH}_{3}\right), 5.42\left(2 \mathrm{H}, \mathrm{s}, \mathrm{OCH}_{2}\right), 5.52(1 \mathrm{H}, \mathrm{m}, \mathrm{N}-\mathrm{CH}-\mathrm{Ph}), 7.28-7.84$ $\left(10 \mathrm{H}, \mathrm{m}\right.$, aromatic); ${ }^{13} \mathrm{C}-\mathrm{NMR}\left(100 \mathrm{MHz}, \mathrm{DMSO}-d_{6}\right) ; \delta_{\mathrm{C}}(\mathrm{ppm}) 11.59\left(\mathrm{CH}_{3}\right), 21.23,23.61\left(\mathrm{~N}-\mathrm{CH}_{2}-\mathrm{CH}_{2}\right)$, $31.09\left(\mathrm{C}\left(\underline{\mathrm{CH}}_{3}\right)_{3}\right), 48.09\left(\mathrm{~N}-\mathrm{CH}_{2}-\underline{\mathrm{CH}}_{2}\right), 58.23(\mathrm{~N}-\underline{\mathrm{CH}}-\mathrm{Ph}), 58.60,69.39,123.98,125.36,126.87,128.24$, $128.60,129.79,130.25,136.13,138.14,142.16,166.65$, and 166.24 (carbon of ester carbonyl); ESI-MS: $\mathrm{m} / \mathrm{z}$ $447\left([\mathrm{M}+\mathrm{H}]^{+}, 100 \%\right)$;Anal. Calcd for $\mathrm{C}_{27} \mathrm{H}_{34} \mathrm{~N}_{4} \mathrm{O}_{2}: \mathrm{C}, 72.62 ; \mathrm{H}, 7.67 ; \mathrm{N}, 12.55$ Found C, 72.74; $\mathrm{H}, 7.78$; $\mathrm{N}, 12.62$.

(1R,2S)- (1-(1-Phenyl-2-(pyrrolidin-1-yl)propyl)-1H-1,2,3-triazol-4-yl)methyl 3-methylbenzoate, (5j)

Pale brown solid, yield 84\%, MP: $150-152{ }^{\circ} \mathrm{C}$, IR $\left(\mathrm{KBr}^{\mathrm{cm}}{ }^{-1}\right)$ : 1707, 1589, 1389, 1277, 1053, 953, 859, and 770; ${ }^{1} \mathrm{H}-\mathrm{NMR}\left(400 \mathrm{MHz}\right.$, DMSO- $\left.d_{6}\right) ; \delta_{\mathrm{H}}(\mathrm{ppm}) 0.93\left(3 \mathrm{H}, \mathrm{d}, J=6.2 \mathrm{~Hz}, \mathrm{CH}_{3}\right), 1.56\left(4 \mathrm{H}, \mathrm{m}\right.$, two $\mathrm{CH}_{2}{ }^{\prime} \mathrm{s}$ of pyrrolidinyl ring at $\left.\mathrm{C}_{3} \& \mathrm{C}_{4}\right), 2.37\left(3 \mathrm{H}, \mathrm{s}, \mathrm{Ph}-\mathrm{CH}_{3}\right) 2.49-2.56\left(\mathrm{~m}, 4 \mathrm{H}\right.$, two $\mathrm{CH}_{2}{ }^{\prime} \mathrm{s}$ of pyrrolidinyl ring at $\left.\mathrm{C}_{2} \& \mathrm{C}_{5}\right), 3.83-3.86\left(1 \mathrm{H}, \mathrm{m}, \mathrm{CH}-\mathrm{CH}_{3}\right), 5.45\left(2 \mathrm{H}, \mathrm{s}, \mathrm{OCH}_{2}\right), 5.48-5.52(1 \mathrm{H}, \mathrm{m}, \mathrm{N}-\mathrm{CH}-\mathrm{Ph}), 7.27-7.84$ $\left(10 \mathrm{H}, \mathrm{m}\right.$, aromatic); ${ }^{13} \mathrm{C}-\mathrm{NMR}\left(100 \mathrm{MHz}, \mathrm{DMSO}-d_{6}\right) ; \delta_{\mathrm{C}}(\mathrm{ppm}) 11.59\left(\mathrm{CH}_{3}\right), 21.23\left(\mathrm{C}_{3} \& \mathrm{C}_{4}\right.$ carbon of pyrrolidinyl ring), $23.61\left(\mathrm{CH}_{3}\right.$ attached to phenyl ring), 48.09 ( $\mathrm{C}_{2} \& \mathrm{C}_{5}$ carbons of pyrrolidinyl ring), $58.23\left(\underline{\mathrm{CH}}-\mathrm{CH}_{3}\right), 58.6\left(\underline{\mathrm{CH}}-\mathrm{CH}-\mathrm{CH}_{3}\right), 69.39\left(\mathrm{O}-\mathrm{CH}_{2}\right), 123.33,126.87,127.24,128.60,129.79,133.88$, 137.56, 138.14, 142.16, and 166.65 (ester carbonyl); ESI-MS: $m / z 405$ (M + H, 100\%); Anal. Calcd for $\mathrm{C}_{24} \mathrm{H}_{28} \mathrm{~N}_{4} \mathrm{O}_{2}$ : C, 71.26; H, 6.98; N, 13.85 Found C, 71.38; H, 7.07; N, 13.97.

(1R,2S)- (1-(1-Phenyl-2-(pyrrolidin-1-yl)propyl)-1H-1,2,3-triazol-4-yl)methyl 2-chlorobenzoate, (5k)

Brownish yellow solid, yield 79\%, MP: 101-102 ${ }^{\circ} \mathrm{C}$, IR (KBr, cm $\left.{ }^{-1}\right): 1719,1589,1391,1265,1049$, 943, 851, and 768; ${ }^{1} \mathrm{H}-\mathrm{NMR}\left(400 \mathrm{MHz}, \mathrm{DMSO}-d_{6}\right) ; \delta_{\mathrm{H}}(\mathrm{ppm}) 0.98\left(3 \mathrm{H}, \mathrm{d}, J=6.2 \mathrm{~Hz}, \mathrm{CH}_{3}\right), 1.53(4 \mathrm{H}$, $\mathrm{m}$, two $\mathrm{CH}_{2}{ }^{\prime}$ s of pyrrolidinyl ring at $\left.\mathrm{C}_{3} \& \mathrm{C}_{4}\right), 2.56\left(\mathrm{~m}, 4 \mathrm{H}\right.$, two $\mathrm{CH}_{2}{ }^{\prime}$ s of pyrrolidinyl ring at $\mathrm{C}_{2}$ \& $\left.\mathrm{C}_{5}\right), 3.94\left(1 \mathrm{H}, \mathrm{m}, \mathrm{CH}-\mathrm{CH}_{3}\right), 5.47\left(2 \mathrm{H}, \mathrm{s}, \mathrm{OCH}_{2}\right), 5.64(1 \mathrm{H}, \mathrm{m}, \mathrm{N}-\mathrm{CH}-\mathrm{Ph}), 7.28-7.86(10 \mathrm{H}, \mathrm{m}$, aromatic); ${ }^{13} \mathrm{C}-\mathrm{NMR}\left(100 \mathrm{MHz}, \mathrm{DMSO}-d_{6}\right) ; \delta_{\mathrm{C}}(\mathrm{ppm}) 11.81\left(\mathrm{CH}_{3}\right), 21.23\left(\mathrm{C}_{3} \& \mathrm{C}_{4}\right.$ carbon of pyrrolidinyl ring), $48.42\left(\mathrm{C}_{2} \& \mathrm{C}_{5}\right.$ carbons of pyrrolidinyl ring $), 49.82\left(\mathrm{CH}-\mathrm{CH}_{3}\right), 59.12\left(\mathrm{CH}-\mathrm{CH}-\mathrm{CH}_{3}\right), 71.98\left(\mathrm{O}-\mathrm{CH}_{2}\right)$, 122.24, 123.91, 124.11, 126.34, 128.44, 129.06, 130.36, 135.66, 136.15, 137.23, 138.23, 149.10, and 166.23 (ester carbonyl); ESI-MS: $[\mathrm{M}+\mathrm{H}]^{+}$at $\mathrm{m} / \mathrm{z} 425$ and 427 in the ratio of 3:1; Anal. Calcd for $\mathrm{C}_{23} \mathrm{H}_{25} \mathrm{ClN}_{4} \mathrm{O}_{2}$ : C, 65.01, H, 5.93; N, 13.19 Found C, 65.13; H, 5.98; N, 13.27.

(1R,2S)-((1-(1-Phenyl-2-(pyrrolidin-1-yl)propyl)-1H-1,2,3-triazol-4-yl)methyl 2-phenylbutanoate, (51)

Brown solid, yield 70\%, MP: 127-129 ${ }^{\circ} \mathrm{C}$, IR $\left(\mathrm{KBr}, \mathrm{cm}^{-1}\right)$ : 1738, 1601, 1381, 1032, 997, 851, and 770; ${ }^{1} \mathrm{H}-\mathrm{NMR}\left(400 \mathrm{MHz}, \mathrm{DMSO}-d_{6}\right) ; \delta_{\mathrm{H}}(\mathrm{ppm}) 0.82\left(3 \mathrm{H}, \mathrm{t}, J=7.3 \mathrm{~Hz}, \mathrm{CH}_{2}-\mathrm{CH}_{3}\right), 0.98(3 \mathrm{H}, \mathrm{t}, J=6.4 \mathrm{~Hz}$, $\left.\mathrm{CH}_{3}\right), 1.60-163\left(4 \mathrm{H}, \mathrm{m}\right.$, two $\mathrm{CH}_{2}{ }^{\prime}$ s of pyrrolidinyl ring at $\left.\mathrm{C}_{3} \& \mathrm{C}_{4}\right), 1.76-1.78(1 \mathrm{H}, \mathrm{m}), 2.04-2.06(1 \mathrm{H}$, $\mathrm{m}), 2.50-2.67(4 \mathrm{H}, \mathrm{m}), 3.44-3.47\left(1 \mathrm{H}, \mathrm{m}, \mathrm{CH}-\mathrm{CH}_{3}\right), 3.84(\mathrm{~m}, 1 \mathrm{H}), 5.16-5.24\left(\mathrm{~m}, 2 \mathrm{H}, \mathrm{OCH}_{2}\right), 5.56(1 \mathrm{H}, \mathrm{m})$, 7.26-7.59 (11H, m, aromatic); ${ }^{13} \mathrm{C}-\mathrm{NMR}\left(100 \mathrm{MHz}, \mathrm{DMSO}-d_{6}\right) ; \delta_{\mathrm{C}}(\mathrm{ppm}) 12.07\left(\mathrm{CH}_{2}-\mathrm{CH}_{3}\right), 18.12\left(\mathrm{CH}_{3}\right)$, 
$23.55\left(\mathrm{CH}_{2}-\mathrm{CH}_{3}\right), 26.66\left(\mathrm{C}_{3} \& \mathrm{C}_{4}\right.$ carbon of pyrrolidinyl ring), $48.69\left(\mathrm{C}_{2} \& \mathrm{C}_{5}\right.$ carbons of pyrrolidinyl ring), $53.22\left(\underline{\mathrm{CH}}-\mathrm{CH}_{3}\right), 58.02((\mathrm{C}=\mathrm{O})-\mathrm{CH}-\mathrm{Ph}), 59.11\left(\mathrm{C} H-\mathrm{CH}-\mathrm{CH}_{3}\right), 68.79\left(\mathrm{O}-\mathrm{CH}_{2}\right), 123.59,127.23$, $127.77,127.96,128.55,128.68,128.97,137.43,138.77,142.48$, and 173.88 (ester carbonyl); ESI-MS: $\mathrm{m} / \mathrm{z}$ $433[\mathrm{M}+\mathrm{H}]^{+}, 100 \%$; Anal. Calcd for $\mathrm{C}_{26} \mathrm{H}_{32} \mathrm{~N}_{4} \mathrm{O}_{2}$ : C, 72.19; H, 7.46; N, 12.95 Found $\mathrm{C}, 72.33 ; \mathrm{H}, 7.54$; N, 12.99.

Recovery and reuse of catalyst $\mathrm{CuI} / \mathrm{Al}_{2} \mathrm{O}_{3}$ : The recovered catalyst from the reaction was washed thoroughly with methanol and dried at $75{ }^{\circ} \mathrm{C}$ for $6 \mathrm{~h}$ and reused. During this study, we used the catalyst ten times with the same activity in terms of the progress of the reaction, which was generally completed in $16-20 \mathrm{~h}$. The reaction time was increased to $20-30 \mathrm{~h}$ for the subsequent reactions using the recycled catalyst after 10 cycles.

\section{Conclusions}

In summary, copper-iodide-infused neutral alumina catalyst was developed and used for the efficient synthesis of 1,4-disubstituted-1,2,3-triazoles 5a-1 using a click chemistry approach from pyrrolidinylnorephedrine 1 . The advantages of the prepared catalyst over previous reports were its easy preparation, fast reaction times, and recyclability of the used catalyst. This effective heterogeneous catalyst was reused for ten cycles by isolating the desired product in high yields using simple filtration. The obtained compounds $5 \mathbf{a}-\mathbf{1}$ showed good antimicrobial activities when compared with standard drugs streptomycin and ketoconazole. Triazoles $\mathbf{5 a}, \mathbf{5 e}$, and $\mathbf{5 g}-\mathbf{j}$, which had high antimicrobial activities were also screened for cytotoxicity activity and were found to have influential cytotoxicity activities against A549 and HepG-2 cell lines. Among these tested compounds, $\mathbf{5 g}$ and $\mathbf{5 h}$ showed potent cytotoxic activity. In order to rationalize the biological studies, the docking was done with the DNA topoisomerase IV and anaplastic lymphoma kinase receptors. The studies revealed that the synthesized compounds exhibited better binding energy with the targeted receptors.

Supplementary Materials: The supplementary materials are available at http://www.mdpi.com/1420-3049/24/19/ 3501/s1.

Author Contributions: Synthesis and characterization of the triazole derivatives were performed by K.E., J.A.R., and K.C.R., S.M.M., N.A., A.I.A., R.S.K. and D.M.A. contributed to the synthesis of starting substrates including their structural assignments. C.B. and S.A. performed biological evaluation. Molecular docking studies were done by Y.A.

Funding: This work was funded by the Deanship of Scientific Research at King Saud University for the Research grant RGP-026.

Acknowledgments: The authors sincerely thank the management of Malladi Drugs \& Pharmaceuticals Ltd., Chennai, India for providing the key raw material pyrrolidinynorephedrine and support to this research activity. The authors acknowledge the Deanship of Scientific Research at King Saud University for funding this work through the Research grant RGP-026.

Conflicts of Interest: The authors declare that there is no conflict of interests.

\section{References}

1. Boyd, N.M.; Reade, P.C. Mechanisms of carcinogenesis with particular reference to the oral mucosa. J. Oral Pathol. 1988, 17, 193-201. [CrossRef]

2. Rajeevan, M.S.; Vernon, S.D.; Taysavang, N.; Unger, E.R. Validation of array-based gene expression profiles by real-time (kinetic) RT-PCR. J. Mol. Diagn. 2001, 3, 26-31. [CrossRef]

3. Meinhardt, G.; Wendtner, C.M.; Hallek, M. Molecular pathogenesis of chronic lymphocytic leukemia: Factors and signaling pathways regulating cell growth and survival. J. Mol. Med. 1999, 77, 282-293. [CrossRef] [PubMed]

4. Sastry, K.S.; Karpova, Y.; Prokopovich, S.; Smith, A.J.; Essau, B.; Gersappe, A. Epinephrine protects cancer cells from apoptosis via activation of cAMP-dependent protein kinase and BAD phosphorylation. J. Biol. Chem. 2007, 282, 14094-14100. [CrossRef] 
5. Entschladen, F.; Lang, K.; Drell, T.L.; Joseph, J.; Zaenker, K.S. Neurotransmitters are regulators for the migration of tumor cells and leukocytes. Cancer Immunol. Immunother. 2002, 51, 467-482. [CrossRef] [PubMed]

6. Lang, K.; Drell, T.L.; Lindecke, A.; Niggemann, B.; Kaltschmidt, C.; Zaenker, K.S. Induction of a metastatogenic tumor cell type by neurotransmitters and its pharmacological inhibition by established drugs. Int. J. Cancer 2004, 112, 231-238. [CrossRef] [PubMed]

7. Shang, Z.J.; Liu, K.; Liang, D.F. Expression of beta2-adrenergic receptor in oral squamous cell carcinoma. J. Oral Pathol. Med. 2009, 38, 371-376. [CrossRef] [PubMed]

8. Wu, W.K.; Wong, H.P.; Luo, C.K.; Huang, F.Y.; Hui, M.K. 4-(Methylnitrosamino)-1-(3-pyridyl)-1-butanone from cigarette smoke stimulates colon cancer growth via beta-adrenoceptors. Cancer Res. 2005, 65, 5272-5277. [CrossRef] [PubMed]

9. Wong, H.P.; Yu, L.; Lam, E.K.; Tai, E.K.; Wu, W.K.; Cho, C.H. Nicotine promotes colon tumor growth and angiogenesis through beta-adrenergic activation. Toxicol. Sci. 2007, 97, 279-287. [CrossRef] [PubMed]

10. Steimer, F.; Carmona, A.T.; Moreno-Vargas, A.J.; Caffa, I.; Cea, M.; Montecucco, F.; Nencioni, A.; Vogel, P.; Robina, I. Synthesis of Pyrrolidine 3,4-Diol Derivatives with Anticancer Activity on Pancreatic Tumor Cells. Heterocycles 2014, 88, 1445-1464.

11. Jung, S.H.; Choi, K.; Pae, A.N.; Kyun Lee, J.; Choo, H.; Keum, G.; Cho, Y.S.; Min, S.J. Facile diverted synthesis of pyrrolidinyl triazoles using organotrifluoroborate: Discovery of potential mPTP blockers. Org. Biomol. Chem. 2014, 12, 9674-9682. [CrossRef] [PubMed]

12. Martinez-Bailen, M.; Carmona, A.T.; Nirebi-Clavijo, E.; Robina, I.; Ide, D.; Kato, A.; Moreno-Vargas, A.J. Tuning of $\beta$-glucosidase and $\alpha$-galactosidase inhibition by generation and in situ screening of a library of pyrrolidine-triazole hybrid molecules. Eur. J. Med. Chem. 2017, 138, 532-542. [CrossRef] [PubMed]

13. Kolb, H.C.; Finn, M.G.; Sharpless, K.B. Click Chemistry: Diverse Chemical Function from a Few Good Reactions. Angew. Chem. Int. Ed. 2001, 40, 2004-2021. [CrossRef]

14. Lewis, W.G.; Green, L.G.; Grynszpan, F.; Radic, Z.; Carlier, P.R.; Taylor, P.; Finn, M.G.; Sharpless, K.B. Click Chemistry In Situ: Acetylcholinesterase as a Reaction Vessel for the Selective Assembly of a Femtomolar Inhibitor from an Array of Building Blocks. Angew. Chem. Int. Ed. 2002, 41, 1053-1057. [CrossRef]

15. Easwaramoorthi, K.; Jeya Rajendran, A.; Chennakesava Rao, K.; Arun, Y.; Balachandran, C.; Perumal, P.T.; Emi, N.; Mahalingam, S.M.; Duraipandiyan, V.; Al-Dhabi, N.A. Synthesis of novel 1,4-disubstituted 1,2,3-triazolo-bosentan derivatives-Evaluation of antimicrobial and anticancer activities and molecular docking. RSC Adv. 2015, 5, 105266-105278. [CrossRef]

16. Sandip, A.G.; Shrikant, P.G.; Swapna, G.M.; Vandana, P.S. Alumina-Supported Copper Iodide: An Efficient and Recyclable Catalyst for Microwave-Assisted Synthesis of 1,4-Disubstituted 1,2,3-Triazoles via Three-Component Reaction in Water. Asian J. Org. Chem. 2015, 4, 943-951.

17. Roberts, B.A.; Strauss, C.R. Toward Rapid, “Green”, Predictable Microwave-Assisted Synthesis. Acc. Chem. Res. 2005, 38, 653-661. [CrossRef]

18. Prakasam, T.; Ramana, D.V.; Srinivasan, P.S.; Kumar, B.N.H.; Arabindoo, B. A process for the preparation of N-alkylaminophenyl(pyrrolidinyl)propane hydrochloride derivatives. Indian patent IN2007CH01379; Chennai, India, 2007.

19. Balachandran, C.; Arun, Y.; Duraipandiyan, V.; Ignacimuthu, S.; Balakrishna, K.; Al-Dhabi, N.A. Antimicrobial and cytotoxicity properties of 2,3-dihydroxy-9,10-anthraquinone isolated from Streptomyces galbus (ERINLG-127). Appl. Biochem.Biotechnol. 2014, 17, 3513-3528. [CrossRef]

20. Balachandran, C.; Duraipandiyan, V.; Balakrishna, K.; Lakshmi Sundaram, R.; Vijayakumar, A.; Ignacimuthu, S.; Al-Dhabi, N.A. Synthesis and medicinal properties of plant-derived vilangin. Environ. Chem. Lett. 2013, 11, 303-308. [CrossRef]

21. Balachandran, C.; Chennakesava Rao, K.; Arun, Y.; Emi, N.; Yamamoto, N.; Inaguma, Y.; Okamoto, A.; Easwaramoorthi, K.; Perumal, P.T. Synthetic investigation on chirally pure Mannich derivatives of pseudophenylpropanolamine and their anticancer properties against HepG-2 cells with inhibition of JAK2/STAT3. RSC Adv. 2016, 6, 96946-96962. [CrossRef]

22. Chennakesava Rao, K.; Arun, Y.; Easwaramoorthi, K.; Balachandran, C.; Prakasam, T.; Yuvaraj, T.E.; Perumal, P.T. Synthesis, antimicrobial and molecular docking studies of enantiomerically pure $N$-alkylated $\beta$-amino alcohols from phenylpropanolamines. Bioorg. Med. Chem. Lett. 2014, 24, 3057-3063. [CrossRef] [PubMed] 
23. Chennakesava Rao, K.; Easwaramoorthi, K.; Arun, Y.; Balachandran, C.; Muralidhara Rao, K.S.; Govindhan, M.; Emi, N.; Prakasam, T.; Perumal, P.T. Synthesis of $\mathrm{BF}_{3}$ catalyzed Mannich derivatives with excellent ee from phenylpropanolamine, study of their antimicrobial activity and molecular docking. Bioorg. Med. Chem. Lett. 2015, 25, 4232-4238. [CrossRef] [PubMed]

24. Arun, Y.; Saranraj, K.; Balachandran, C.; Perumal, P.T. Novel spirooxindole-pyrrolidine compounds: Synthesis, anticancer and molecular docking studies. Eur. J. Med. Chem. 2014, 74, 50-64. [CrossRef] [PubMed]

25. Sanner, M.F. Python: A programming language for software integration and development. J. Mol. Graphics Modell. 1999, 17, 57-61.

26. Morris, G.M.; Huey, R.; Lindstrom, W.; Sanner, M.F.; Belew, R.K.; Goodsell, D.S.; Olson, A.J. AutoDock4 and AutoDockTools4: Automated docking with selective receptor flexibility. J. Comput. Chem. 2009, 30, 2785-2791. [CrossRef] [PubMed]

27. Protein Data Bnk. Available online: http://www.rcsb.org/pdb (accessed on 24 September 2019).

Sample Availability: Samples of the compounds are available from the authors.

(C) 2019 by the authors. Licensee MDPI, Basel, Switzerland. This article is an open access article distributed under the terms and conditions of the Creative Commons Attribution (CC BY) license (http://creativecommons.org/licenses/by/4.0/). 